Welding and Mechanical Properties of Cast FAPY (Fe-16 at. \% Al-Based) Alloy Slabs

\section{OAK RIDGE NATIONAL LABORATORY}

MARTIN MARIETTA

V. K. Sikka, G. M. Goodwin, D. J. Alexander, and C. R. Howell 
This report has been reproduced directly from the best available copy.

Available to DOE and DOE contractors from the Office of Scientific and Technical information, P.O. Box 62, Oak Ridge, TN 37831; prices available from (615) 576-8401, FTS 626-8401.

Available to the public from the National Technical Information Service, U.S. Department of Commerce, 5285 Port Royal Rd., Springfield, VA 22161.

This report was prepared as an account of work sponsored by an agency of the United States Government. Neither the United States Government nor any agency thereof, nor any of their employees, makes any warranty, express or implied, or assumes any legal liability or responsibility for the accuracy, completeness, or usefulness of any information, apparatus, product, or process disclosed, or represents that its use would not infringe privately owned rights. Reference herein to any specific commercial product, process, or service by trade name, trademark, manufacturer, or otherwise, does not necessarily constitute or imply its endorsement, recommendation, or favoring by the United States Government or any agency thereof. The views and opinions of authors expressed herein do not necessarily state or reflect those of the United States Government or any agency thereof. 


\section{DISCLAIMER}

Portions of this document may be illegible in electronic image products. Images are produced from the best available original document. 


\section{Metals and Ceramics Division}

\section{WELDING AND MECHANICAL PROPERTIES OF CAST FAPY (Fe-16 at. \% Al-BASED) ALLOY SLABS}

V. K. Sikka, G. M. Goodwin, D. J. Alexander, and C. R. Howell

Date Published: May 1995

\section{Prepared for the}

U.S. Department of Energy Office of Fossil Energy

Advanced Research and Technology Development Components Program

AA 1510100

Prepared by the

OAK RIDGE NATIONAL LABORATORY

Oak Ridge, Tennessee 37831-6285

managed by

MARTIN MARIETTA ENERGY SYSTEMS, INC.

for the

U.S. DEPARTMENT OF ENERGY

under contract DE-AC05-84OR21400 
ming: 


\section{TABLE OF CONTENTS}

\section{Page}

LIST OF FIGURES ……............................................................................... v

LIST OF TABLES ……......................................................................................... vii

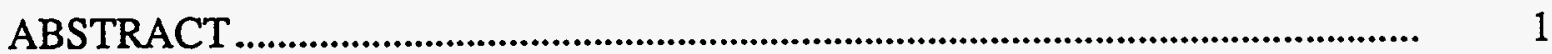

1. INTRODUCTION ................................................................................

2. CASTING …..............................................................................

3. WELD PRODUCTION ........................................................................ 2

4. MECHANICAL PROPERTIES ............................................................. 5

4.1 TENSILE PROPERTIES.....................................................................

4.2 CREEP PROPERTIES ....................................................................

4.3 CHARPY-IMPACT TESTS ..................................................................

5. MICROSTRUCTURE AND HARDNESS DATA ............................................ 14

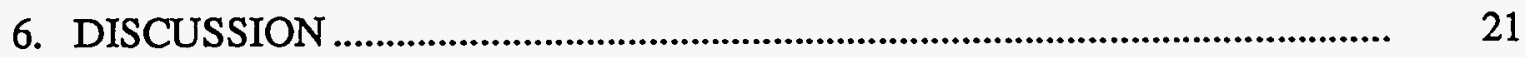

7. SUMMARY AND CONCLUSIONS …......................................................... 23

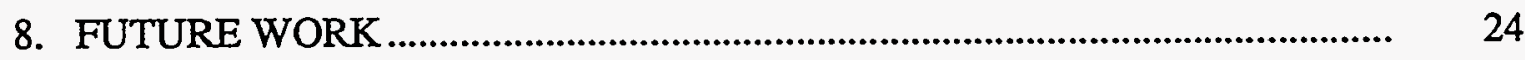

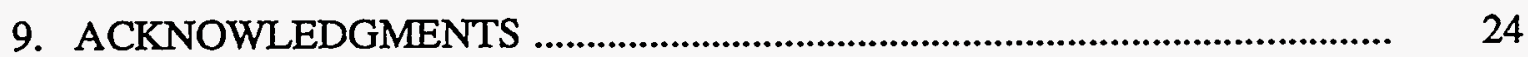

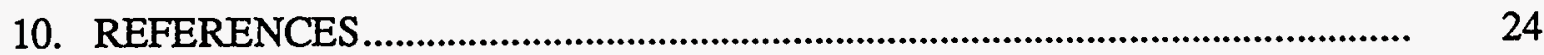




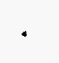




\section{LIST OF FIGURES}

Eigure

Page

1 Joint geometry for FAPY cast slab welds.

$2 \quad$ Macroetched surfaces of gas tungsten arc-processed welds in cast slabs of FAPY alloy

3 Schematic showing the location and size of mechanical property specimens machined from welded slabs of FAPY alloy

4 Comparison of $0.2 \%$ yield strength of weldment specimens with base metal of FAPY alloy. The base-metal data are from a previous study on cast slab

5 Comparison of ultimate tensile strength of weldment specimens with base metal of FAPY alloy. The base-metal data are from a previous study on cast slab

6 Comparison of total elongation of weldment specimens with base metal of FAPY alloy. The base-metal data are from a previous study on cast slab.

7 Comparison of reduction of area of weldment specimens with base metal of FAPY alloy. The base-metal data are from a previous study on cast slab

8 Weldment specimens from 25-mm (1-in.) -thick slab tensile tested at $25^{\circ} \mathrm{C}(1 \mathrm{~L}), 100^{\circ} \mathrm{C}(2 \mathrm{~L}), 200^{\circ} \mathrm{C}(3 \mathrm{~L}), 400^{\circ} \mathrm{C}(4 \mathrm{~L})$, $600^{\circ} \mathrm{C}(5 \mathrm{~L})$, and $800^{\circ} \mathrm{C}(6 \mathrm{~L})$. Note that the failure, in all cases, is in the weld region

9 Comparison of creep-rupture properties of weldment specimens

with the as-cast and wrought base-metal specimens

10 Plot of Charpy-impact energy of weldment specimens from 12-mm (0.5-in.) -thick cast plate of FAPY alloy. Postweld heat treatment was carried out at $750^{\circ} \mathrm{C}$ for $1 \mathrm{~h}$.

11 Comparison of Charpy-impact energy data of weldment specimens with those of base-metal specimens in the wrought condition

12 Optical micrographs of (a) base metal, $(b)$ heat-affected zone, (c) weld top, and (d) weld center in 12-mm (0.5-in.) -thick welded plate of FAPY alloy. Magnification is $50 x$ 
13 Optical micrographs of (a) base metal, $(b)$ heat-affected zone, (c) weld top, and (d) weld center in 25-mm (1-in.) -thick welded plate of FAPY alloy. Magnification is $50 \times$

14 Optical micrographs showing the unusually appearing microstructure in 25-mm (1-in.) -thick plates: (a) base metal and $(b)$ heat-affected zone in the region of unusual base metal. Magnification is $50 x$

15 Optical microstructure of $51-\mathrm{mm}$ (2-in.) -thick base-metal plate of FAPY alloy in the as-cast condition: $(a)$ near surface and (b) near center locations. Magnification is $50 \times$

16 Optical microstructures of weld regions in the 51-mm (2-in.) -thick cast plate of FAPY alloy: (a) weld crown,

$(b)$ weld center, and $(c)$ weld root. Magnification is $50 x$

17 Optical microstructure of heat-affected regions in the 51-mm (2-in.) -thick cast plate of FAPY alloy: (a) near surface and (b) near root locations. Magnification is $50 x$ 


\section{LIST OF TABLES}

Table

Page

$1 \quad$ Welding parameters for cast FAPY alloy slabs ........................................... 3

2 Inspection results of cast FAPY alloy slab welds.......................................... 4

3 Tensile properties of weldment specimens machined from the cast-welded 25- and 51-mm (1- and 2-in.) -thick

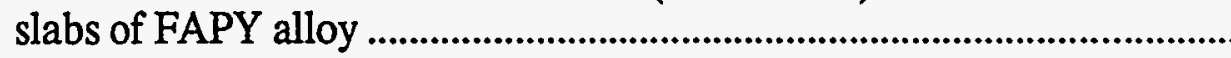

4. Creep properties of weldment specimens ${ }^{a}$ machined from the cast-welded 25-mm (1-in.) -thick slab of FAPY alloy

5 Charpy-impact energy data on weldment specimens from 12 -mm (0.5-in.) -thick plate of FAPY alloy

6 Microhardness of base, weld, and heat-affected zone of welds in 12-, 25-, and 51-mm (0.5-, 1-, and 2-in.) -thick welded plates in the as-cast condition 


\title{
WELDING AND MECHANICAL PROPERTIES OF CAST FAPY (Fe-16 at. \% Al-BASED) ALLOY SLABS*
}

\author{
V. K. Sikka, G. M. Goodwin, D. J. Alexander, and C. R. Howell
}

\begin{abstract}
This report deals with the welding procedure development and weldment properties of an $\mathrm{Fe}-16$ at. \% Al alloy known as FAPY. The welding procedure development was carried out on 12-, 25-, and 51-mm $(0.5-$, $1-$, and 2-in.) -thick plates of the alloy in the as-cast condition. The welds were prepared by using the gas tungsten arc process and filler wire of composition matching the base-metal composition. The preheat temperatures varied from room temperature to $350^{\circ} \mathrm{C}$, and the postweld heat treatment (PWHT) was limited only for $1 \mathrm{~h}$ at $750^{\circ} \mathrm{C}$. The welds were characterized by microstructural analysis and microhardness data. The weldment specimens were machined for Charpy-impact, tensile, and creep properties. The tensile and creep properties of the weldment specimens were essentially the same as that of the base metal. The Charpy-impact properties of the weldment specimens improved with the PWHT and were somewhat lower than previously developed data on the wrought material. Additional work is required on welding of thicker sections, development of PWHT temperatures as a function of section thickness, and mechanical properties.
\end{abstract}

\section{INTRODUCTION}

FAPY is an Fe-16 at. \% Al-based alloy developed at the Oak Ridge National Laboratory as the highest aluminum-containing alloy with essentially no environmental effect. ${ }^{1}$ The chemical composition for FAPY in weight percent is: aluminum $=8.46$, chromium $=5.50$, zirconium $=0.20$, carbon $=0.30$, molybdenum $=2.00$, yttrium $=0.10$, and iron $=83.71$. The cast ingots of the alloy can be hot worked by extrusion, forging, and rolling processes. The hot-worked cast structure can be cold worked with intermediate anneals at $800^{\circ} \mathrm{C}$. Typical room-temperature ductility of the fine-grained wrought structure is 20 to $25 \%$ for this alloy. In contrast to the wrought structure, the ductility of the cast

*Research sponsored by the U.S. Department of Energy, Office of Fossil Energy, Advanced Research and Technology Development Materials Program, [DOE/FE AA 1510 10 0, Work Breakdown Structure Element ORNL-2(H)], under contract DE-AC0584OR21400 with Martin Marietta Energy Systems, Inc. 
structure at room temperature is approximately $1 \%$ with a transition temperature of approximately 100 to $150^{\circ} \mathrm{C}$, above which ductility values exceed $20 \%$. The alloy has been melted and processed into bar, sheet, and foil. The alloy has also been cast into slabs, stepblocks of varying thicknessess, and shapes. The purpose of this report is to describe the welding response of cast slabs of three different thicknesses of FAPY alloy. Tensile, creep, and Charpy-impact data of the welded plates are also presented.

\section{CASTING}

For the welding studies, the FAPY alloy was used in the as-cast condition, prepared by vacuum-induction melting, and cast in graphite molds measuring 100 by $150 \mathrm{~mm}$ ( 4 by 6 in.) in length and having thicknesses of 12,25 , and $51 \mathrm{~mm}(0.5,1$, and 2 in.). All three plates had good as-cast surfaces.

\section{WELD PRODUCTION}

Weld joints were prepared by sawing as shown in Fig. 1. The included angle of $60^{\circ}$ in the double-vee groove geometry was used for all three slab thicknesses and is typical of industrial practice for plate welding.

Weld wire of $3.2 \mathrm{~mm}(0.125 \mathrm{in}$.) diam with a matching composition of FAPY alloy was used for all weldments using the manual gas tungsten arc (GTA) process. The joint surfaces and filler wire were cleaned by wire brushing and solvent degreasing with acetone. A summary of the welding parameters is shown in Table 1.

Preheat, when used, was accomplished with an oxyacetylene torch. Interpass temperature was maintained at $350^{\circ} \mathrm{C}$ minimum. Postweld heat treatment (PWHT), when used, was done immediately following welding in an air furnace followed by free cooling in still air.

Completed weldments were examined for possible defects using liquid-dye penetrant. A summary of the inspection results is shown in Table 2. End sections were removed from each weldment for optical metallography. The macroetched surfaces of the welded slabs are shown in Fig. 2. 
ORNL-DWG 95-5974

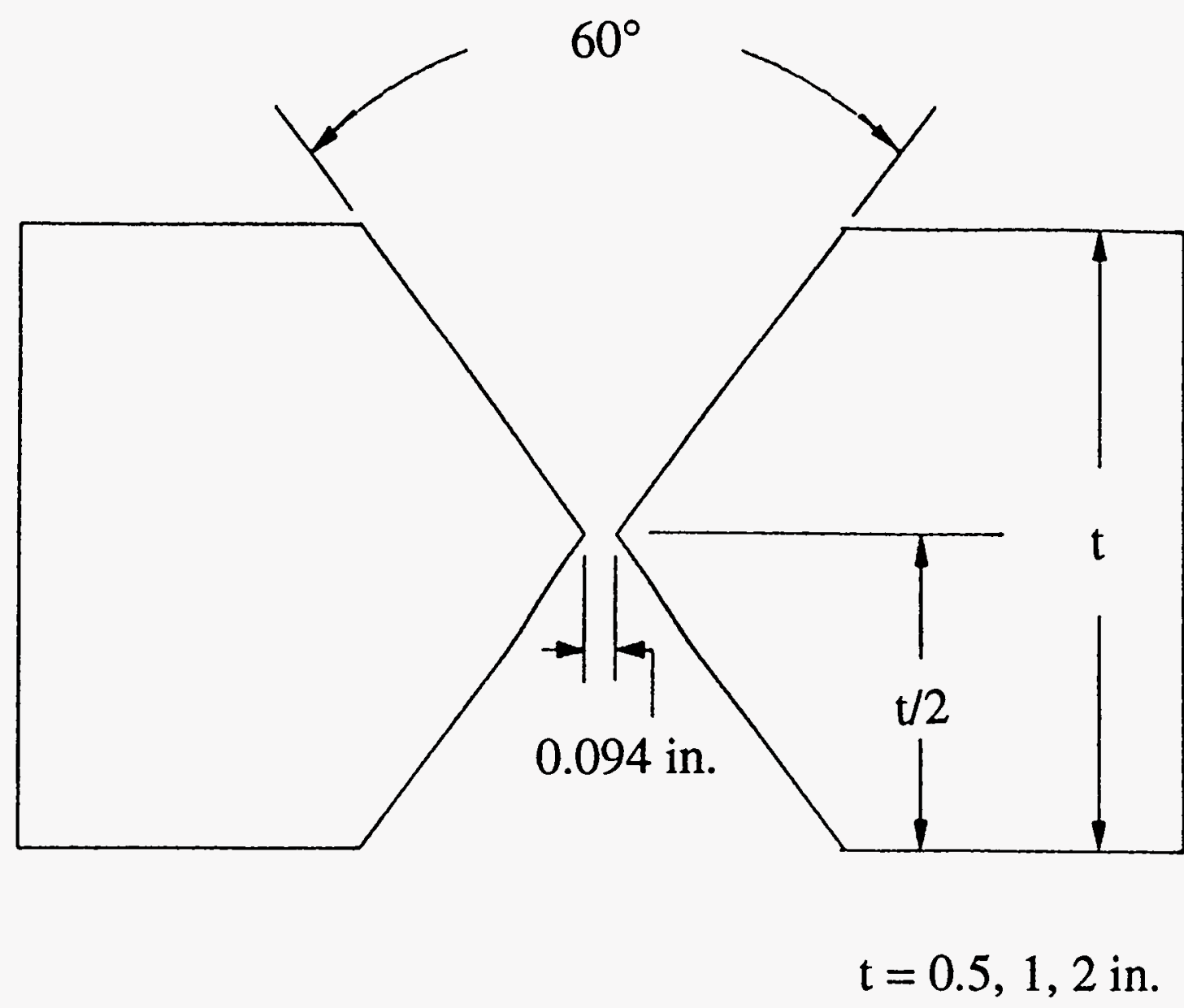

Table 1. Welding parameters for cast FAPY alloy slabs

Process:

Joint geometry:

Base metal:

Filler metal:

Weld current:

Weld voltage:

Torch gas:

Backing gas: $\quad$ Argon, $15 \mathrm{cfh}(7.1 \mathrm{~L} / \mathrm{min})$

Manual gas tungsten arc 2 in.) thicknesses]

10 to $12 \mathrm{~V}$
Double-vee groove, $60^{\circ}$ included angle

Cast slabs $[100 \times 150 \times 12,25$, and $51 \mathrm{~mm}(4 \times 6 \times 0.5,1$, and

3.2-mm (0.125 in.) -diam rod, matching composition

100 to 175 A direct current electrode negative

Argon, $15 \mathrm{cfh}(7.1 \mathrm{~L} / \mathrm{min})$

Argon, $15 \mathrm{cfh}(7.1 \mathrm{~L} / \mathrm{min})$ 
Table 2. Inspection results of cast FAPY alloy slab welds

\begin{tabular}{cccccc}
\hline \multicolumn{2}{c}{ Temperature, ${ }^{\circ} \mathrm{C}$} & & \multicolumn{3}{c}{ Slab thickness, mm (in.) } \\
\cline { 5 - 6 } Preheat & Postheat & & $12(0.5)$ & $25(1)$ & $51(2)$ \\
\hline 350 & 750 & & No cracks & No cracks & No cracks \\
200 & 750 & & -- & -- & No cracks \\
20 & 20 & & No cracks & Cracks & -- \\
\hline
\end{tabular}

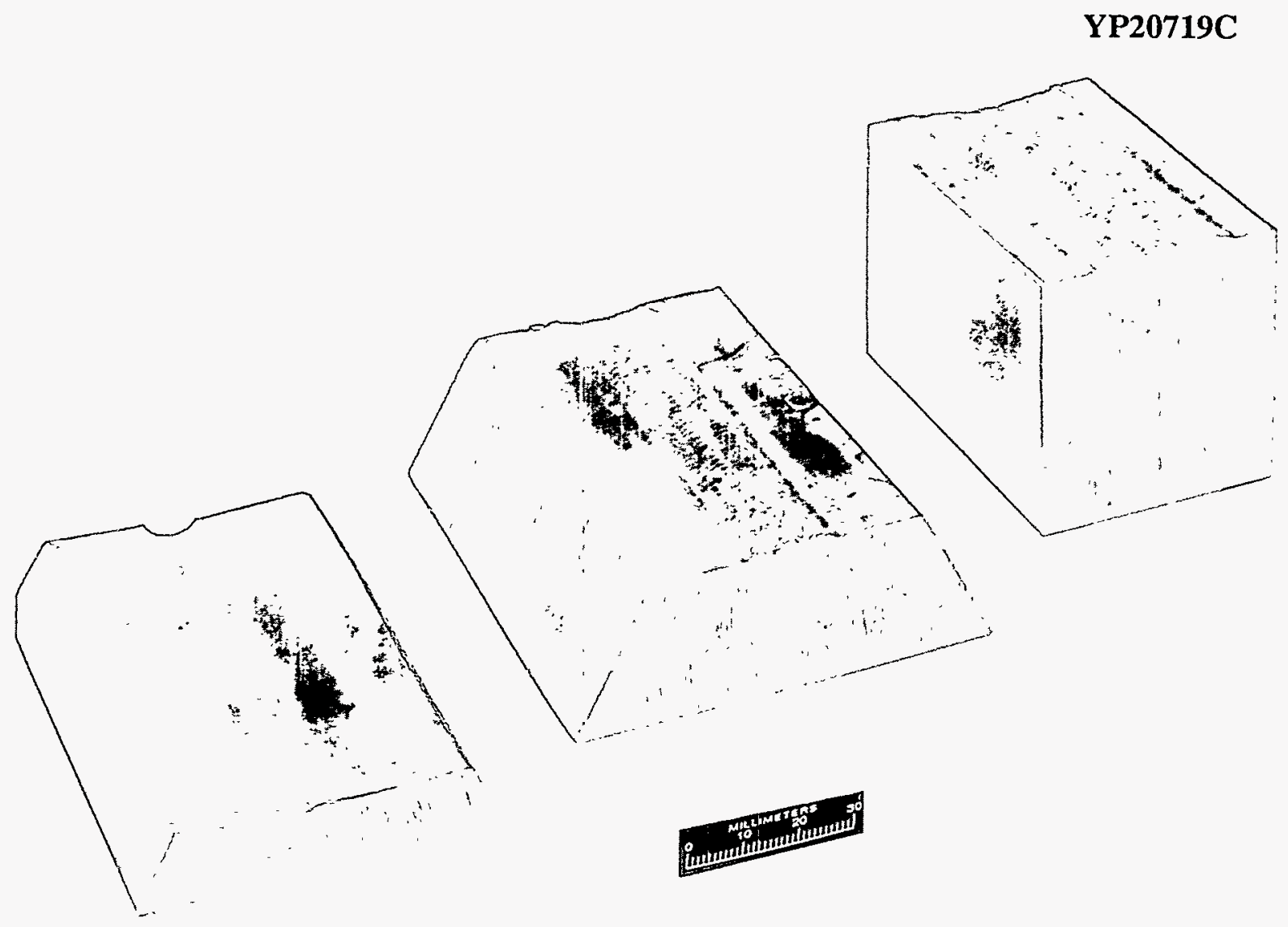

Fig. 2. Macroetched surfaces of gas tungsten arc-processed welds in cast slabs of FAPY alloy. 


\section{MECHANICAL PROPERTIES}

The welded slabs were cut up for mechanical property determinations. The 12-mm (0.5-in.) -thick plates were used for Charpy-impact testing. The 25- and 51-mm (1- and 2-in.) -thick plates were used for tensile and creep properties. The specimen cut-up diagrams for the Charpy, tensile, and creep specimens are shown in Fig. 3.

ORNL-DWG 95-5975
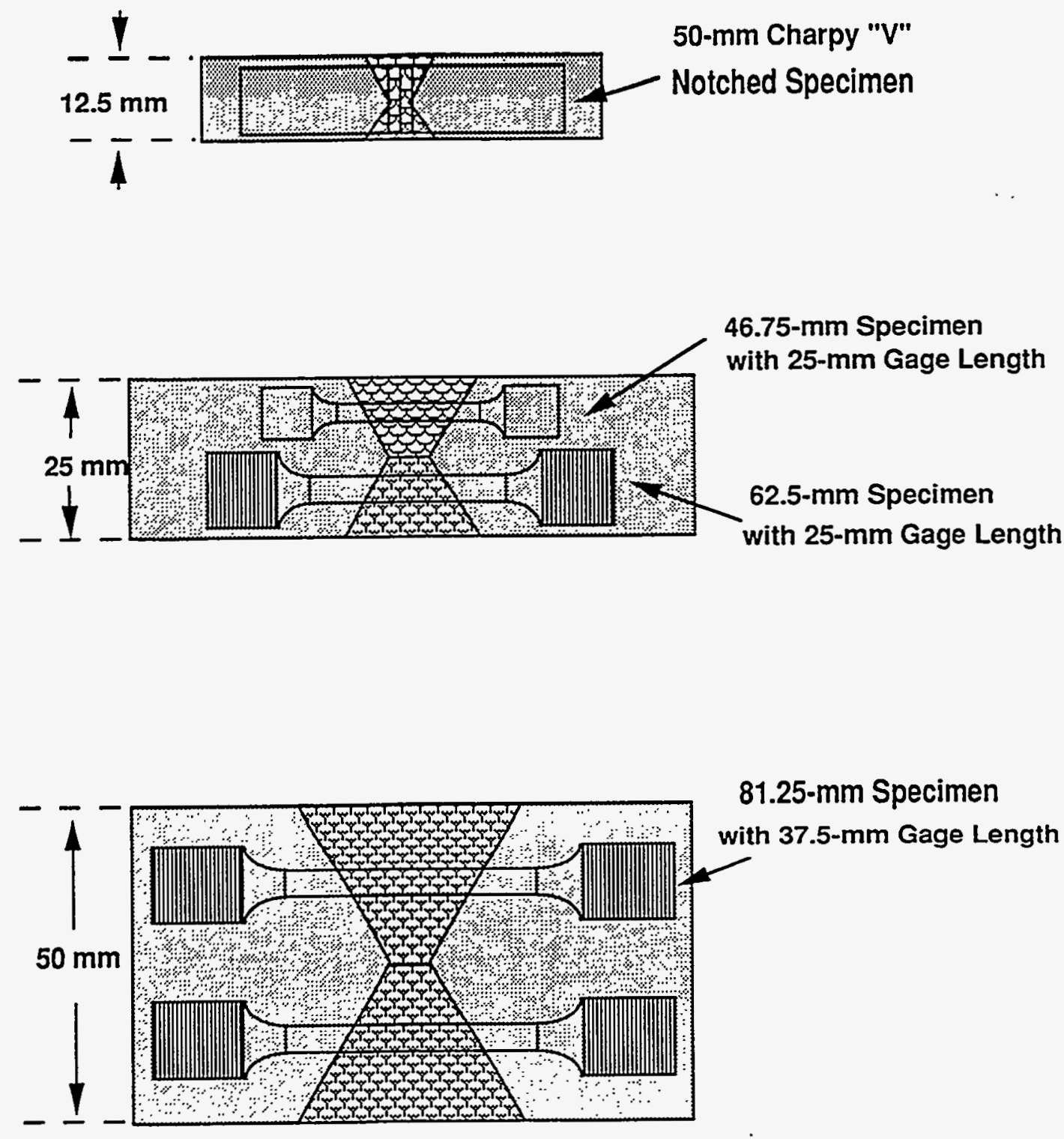

Fig. 3. Schematic showing the location and size of mechanical property specimens machined from welded slabs of FAPY alloy. 


\subsection{TENSILE PROPERTIES}

The tensile data from room temperature to $800^{\circ} \mathrm{C}$ for the $25-$ and $51-\mathrm{mm}$ (1- and 2-in.) -thick welded plates are summarized in Table 3. The strength and ductility data of the weldments are plotted and compared with the base-metal data of the cast slabs in Figs. 4 through 7. The following observations can be seen from these figures:

1. The $0.2 \%$ yield strength of the weldment specimens is essentially the same as the basemetal values for the entire temperature range. This is true for specimens taken from both the 25- and 51-mm (1- and 2-in.) -thick welded plates.

2. The ultimate tensile strength of the weldment specimens from the $51-\mathrm{mm}$ (2-in.) -thick plate showed lower values than the base metal in the test-temperature range up to $200^{\circ} \mathrm{C}$. This is the same temperature region where ductility of both base metal and weldments is low (see Figs. 6 and 7). The observed results in Fig. 5 imply that the weldment specimens from the 51-mm (2-in.) -thick plates are slightly more brittle in this temperature range than base metal or 25 -mm (1-in.) -thick plate.

3. The general trend of total elongation and reduction of area of weldments is the same as that for the base metal (see Figs. 6 and 7).

Broken tensile specimens in Fig. 8 show that all failures between room temperature to $800^{\circ} \mathrm{C}$ were in the weld region.

\subsection{CREEP PROPERTIES}

The creep data on three weldment specimens machined from 25-mm (1-in.) -thick welded plate are summarized in Table 4. The creep-rupture data on the weldment specimens are compared with the previously developed data on as-cast and wrought basemetal specimens in Fig. 9 which shows that although limited in number, the short-term data on weldment specimens match the data on base-metal, as-cast, and wrought specimens. It should be recognized that long-term data are required to further confirm these observations.

\subsection{CHARPY-IMPACT TESTS}

Full-size Charpy-impact specimens were machined from two welded plates of 12-mm (0.5-in.) thickness. One of the plates contained a weld in the as-welded condition, and the other one was given a PWHT at $750^{\circ} \mathrm{C}$ for $1 \mathrm{~h}$. The schematic in Fig. 3 shows the orientation of the Charpy specimens. The crack growth was parallel to the welding 
Table 3. Tensile properties of weldment specimens machined from the cast-welded 25- and 51-mm (1- and 2-in.) -thick slabs of FAPY alloy

\begin{tabular}{|c|c|c|c|c|c|c|c|}
\hline \multirow{2}{*}{$\begin{array}{l}\text { Specimen } \\
\text { No. }\end{array}$} & \multirow{2}{*}{$\begin{array}{c}\text { Test } \\
\text { temperature } \\
\left({ }^{\circ} \mathrm{C}\right)\end{array}$} & \multicolumn{2}{|c|}{$\begin{array}{l}\text { Heat-treatment } \\
\text { temperature }\left({ }^{\circ} \mathrm{C}\right)\end{array}$} & \multirow{2}{*}{$\begin{array}{l}\text { Yield } \\
\text { strength } \\
\text { (MPa) }\end{array}$} & \multirow{2}{*}{$\begin{array}{c}\text { Tensile } \\
\text { strength } \\
\text { (MPa) }\end{array}$} & \multirow{2}{*}{$\begin{array}{c}\text { Total } \\
\text { elongation } \\
(\%)\end{array}$} & \multirow{2}{*}{$\begin{array}{l}\text { Reduction } \\
\text { of area } \\
(\%)\end{array}$} \\
\hline & & Preheat & Postheat $^{a}$ & & & & \\
\hline $1 \mathrm{~L}^{b}$ & 23 & 350 & 750 & 70.91 & 70.91 & 1.79 & 0.08 \\
\hline $2 \mathrm{~L}^{b}$ & 100 & 350 & 750 & 60.31 & 79.81 & 22.88 & 32.53 \\
\hline $3 \mathrm{~L}^{b}$ & 200 & 350 & 750 & 47.91 & 75.07 & 24.32 & 44.38 \\
\hline $4 \mathrm{~L}^{b}$ & 400 & 350 & 750 & 41.19 & 76.78 & 25.58 & 42.89 \\
\hline $5 \mathrm{~L}^{b}$ & 600 & 350 & 750 & 39.26 & 39.50 & 46.16 & 74.71 \\
\hline $6 \mathrm{~L}^{b}$ & 800 & 350 & 750 & 11.82 & 12.22 & 78.24 & 83.80 \\
\hline $11 L^{c}$ & 23 & 200 & 750 & 65.39 & 65.39 & 0.91 & 0.00 \\
\hline $12 \mathrm{~L}^{\mathrm{C}}$ & 50 & 200 & 750 & 64.43 & 65.14 & 1.62 & 0.40 \\
\hline $13 \mathrm{~L}^{c}$ & 100 & 200 & 750 & 57.09 & 73.77 & 9.20 & 9.28 \\
\hline $14 \mathrm{~L}^{c}$ & 200 & 200 & 750 & 45.36 & 71.94 & 20.46 & 50.37 \\
\hline $15 \mathrm{~L}^{c}$ & 400 & 200 & 750 & 37.04 & 73.36 & 26.35 & 41.20 \\
\hline $16 \mathrm{~L}^{c}$ & 600 & 200 & 750 & 37.81 & 38.93 & 43.74 & 72.05 \\
\hline $17 \mathrm{~L}^{c}$ & 800 & 200 & 750 & -- & 11.53 & 64.13 & 80.37 \\
\hline
\end{tabular}

aTime at temperature: $1 \mathrm{~h}$.

bSpecimen gauge length: $25 \mathrm{~mm}$ (1 in.); strain rate: $3.3 \times 10^{-3} / \mathrm{s}$.

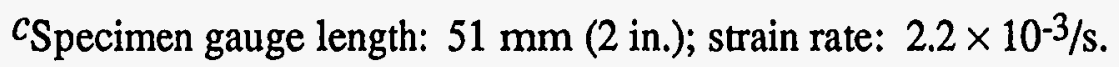


ORNL-DWG95-5976

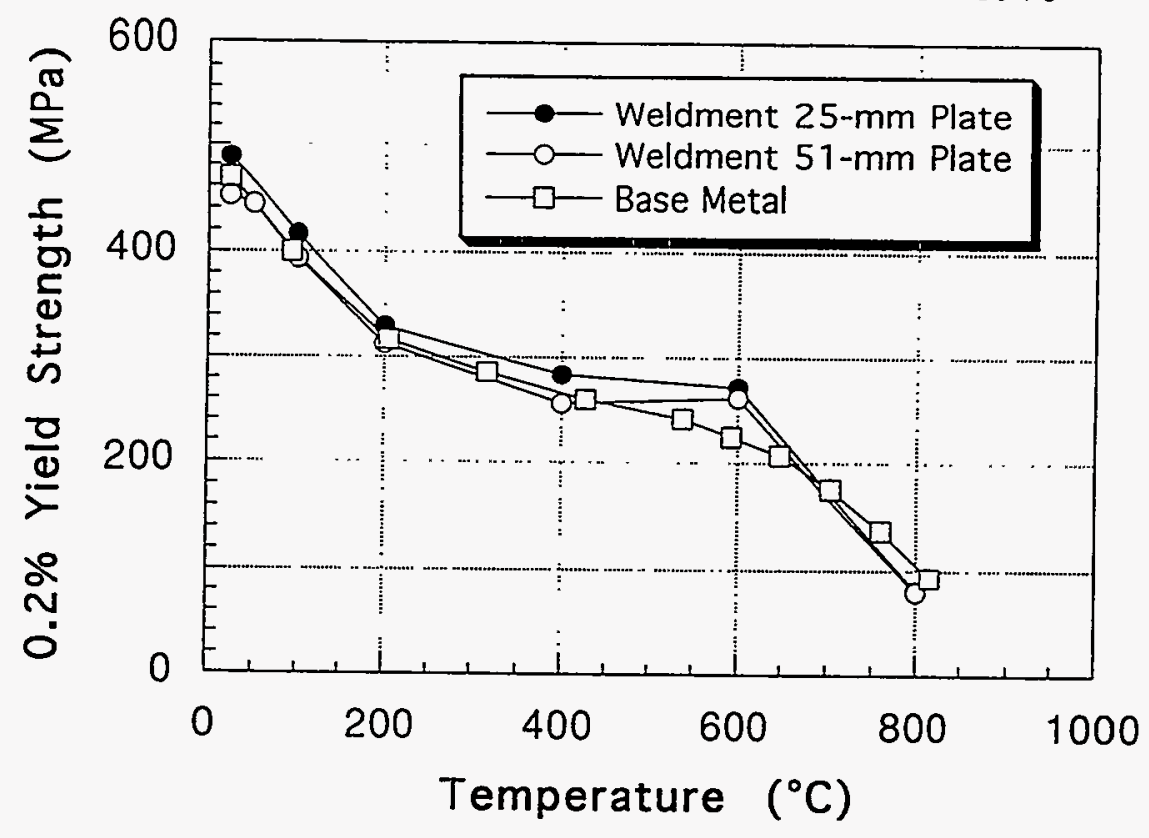

Fig. 4. Comparison of $0.2 \%$ yield strength of weldment specimens with base metal of FAPY alloy. The base-metal data are from a previous study on cast slab.

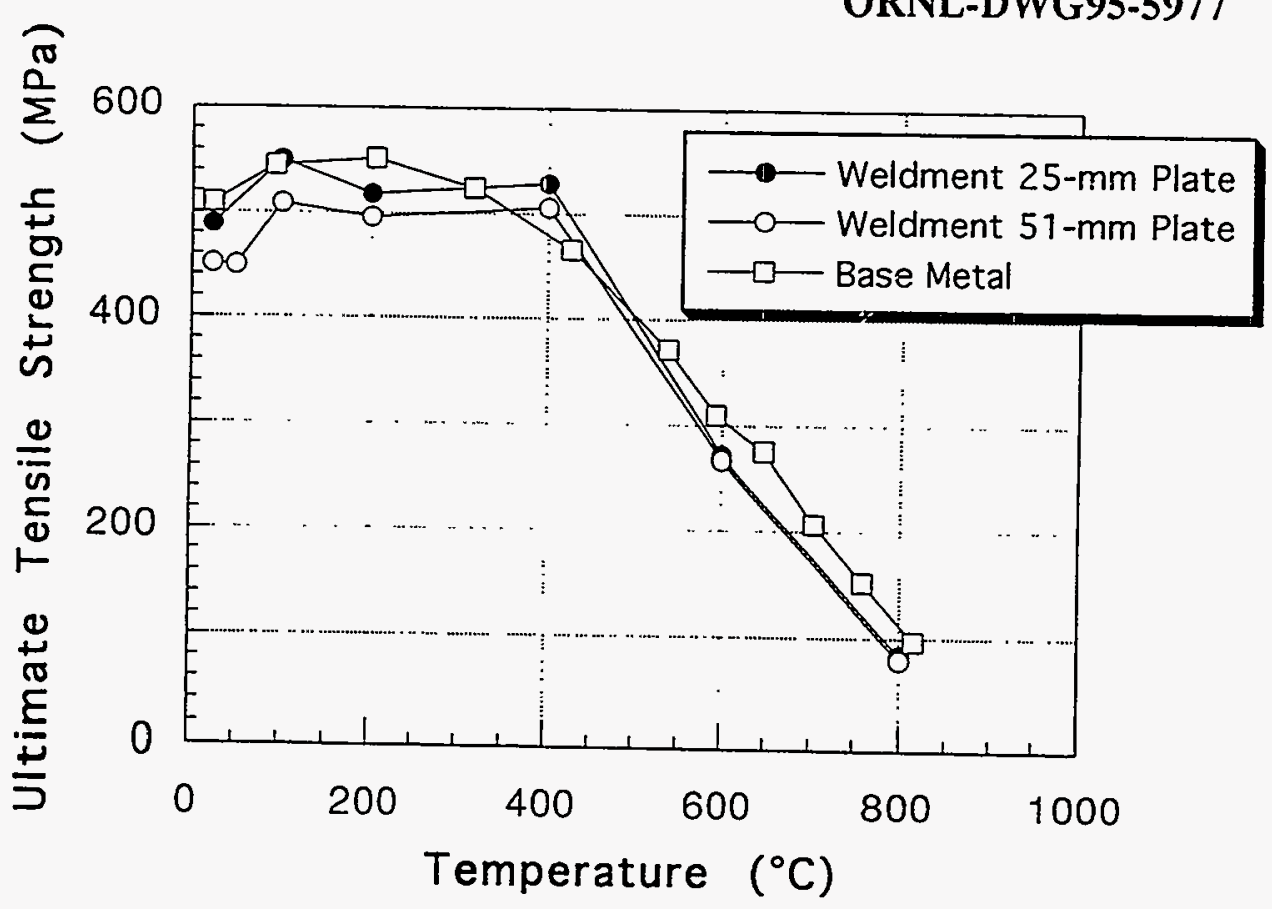

Fig. 5. Comparison of ultimate tensile strength of weldment specimens with base metal of FAPY alloy. The base-metal data are from a previous study on cast slab. 


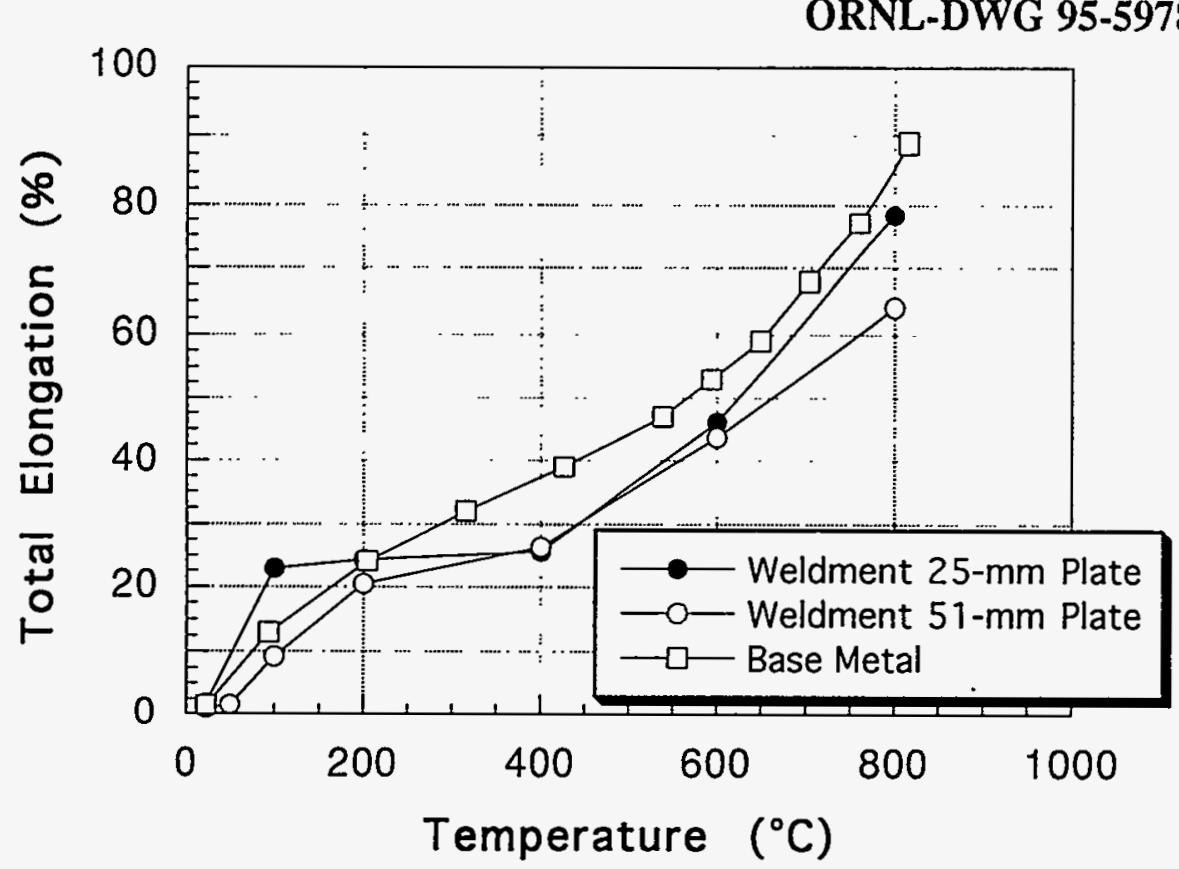

Fig. 6. Comparison of total elongation of weldment specimens with base metal of FAPY alloy. The base-metal data are from a previous study on cast slab.

ORNL-DWG 95-5979

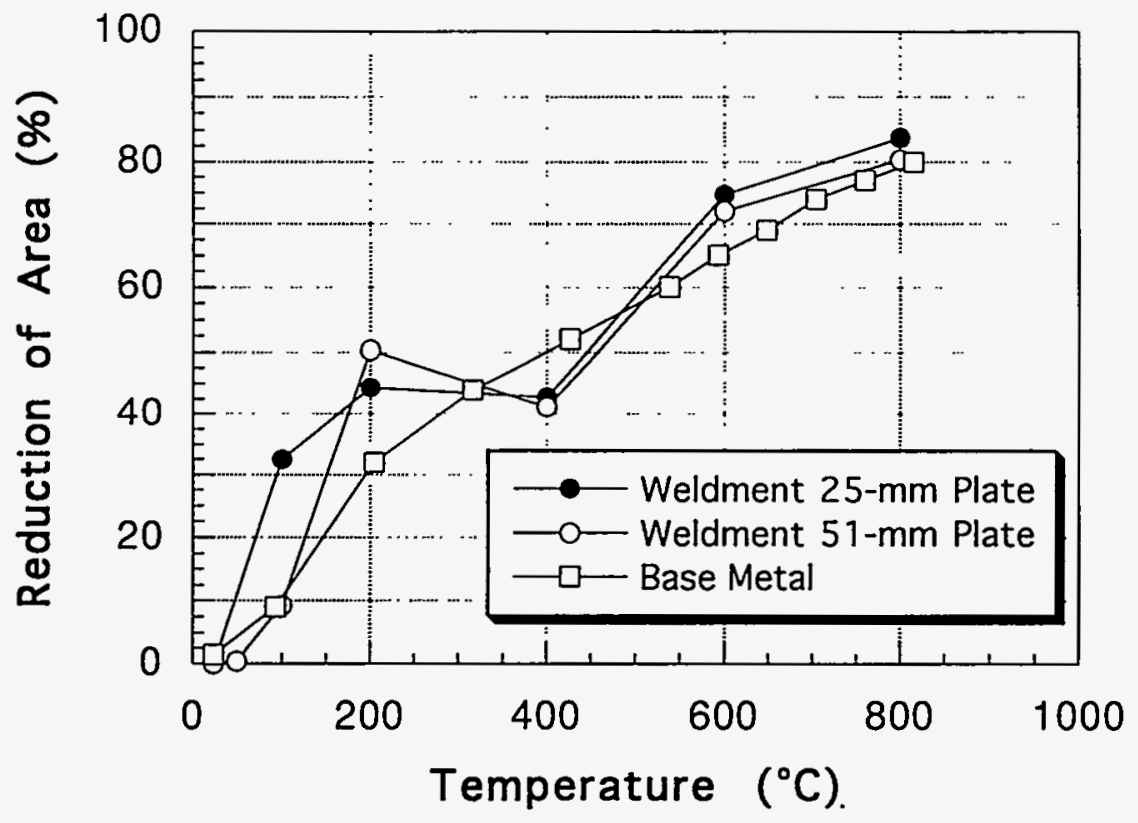

Fig. 7. Comparison of reduction of area of weldment specimens with base metal of FAPY alloy. The base-metal data are from a previous study on cast slab. 


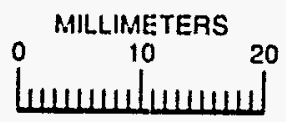

$1 L$

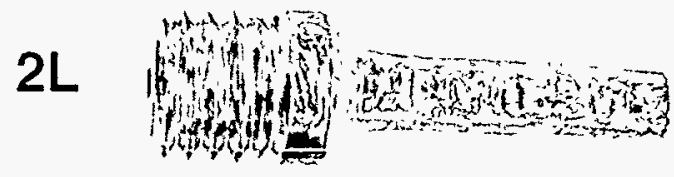

$3 \mathrm{~L}$

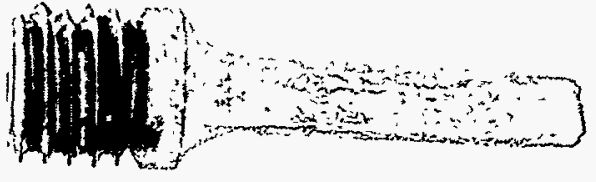

$4 \mathrm{~L}$

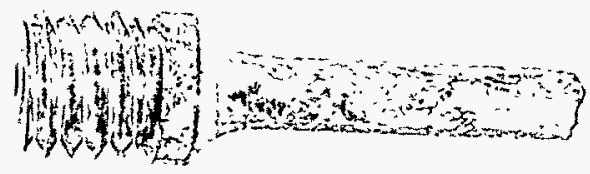

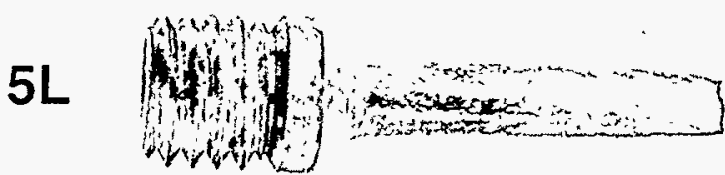

$6 \mathrm{~L}$

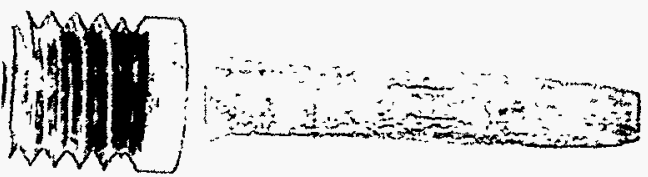

Fig. 8. Weldment specimens from 25-mm (1-in.) -thick slab tensile tested at $25^{\circ} \mathrm{C}(1 \mathrm{~L}), 100^{\circ} \mathrm{C}(2 \mathrm{~L}), 200^{\circ} \mathrm{C}(3 \mathrm{~L}), 400^{\circ} \mathrm{C}(4 \mathrm{~L}), 600^{\circ} \mathrm{C}$ $(5 \mathrm{~L})$, and $800^{\circ} \mathrm{C}(6 \mathrm{~L})$. Note that the failure, in all cases, is in the weld region. 
Table 4. Creep properties of weldment specimens ${ }^{a}$ machined from the cast-welded 25-mm (1-in.) -thick slab of FAPY alloy

\begin{tabular}{rcccccc}
\hline $\begin{array}{c}\text { Test } \\
\text { No. }\end{array}$ & $\begin{array}{c}\text { Specimen } \\
\text { No. }\end{array}$ & $\begin{array}{c}\text { Test } \\
\text { temperature } \\
\left({ }^{\circ} \mathrm{C}\right)\end{array}$ & $\begin{array}{c}\text { Stress } \\
(\mathrm{MPa})\end{array}$ & $\begin{array}{c}\text { Time to } \\
\text { rupture } \\
(\mathrm{h})\end{array}$ & $\begin{array}{c}\text { Rupture } \\
\text { elongation } \\
(\%)\end{array}$ & $\begin{array}{c}\text { Reduction } \\
\text { of area } \\
(\%)\end{array}$ \\
\hline 28312 & 7L & 550 & 207 & 2.2 & 19.20 & 64.94 \\
28321 & 8L & 600 & 138 & 2.8 & 30.38 & 67.08 \\
28314 & 9L & 650 & 69 & 13.6 & 55.96 & 75.89 \\
28313 & 10L & 700 & 20.69 & 1389.3 & 48.90 & 85.90 \\
\hline
\end{tabular}

${ }^{a}$ Weldment prepared with a preheat of $350^{\circ} \mathrm{C}$ and a postweld heat treatment at $750^{\circ} \mathrm{C}$ for $1 \mathrm{~h}$. 
ORNL-DWG95-5980

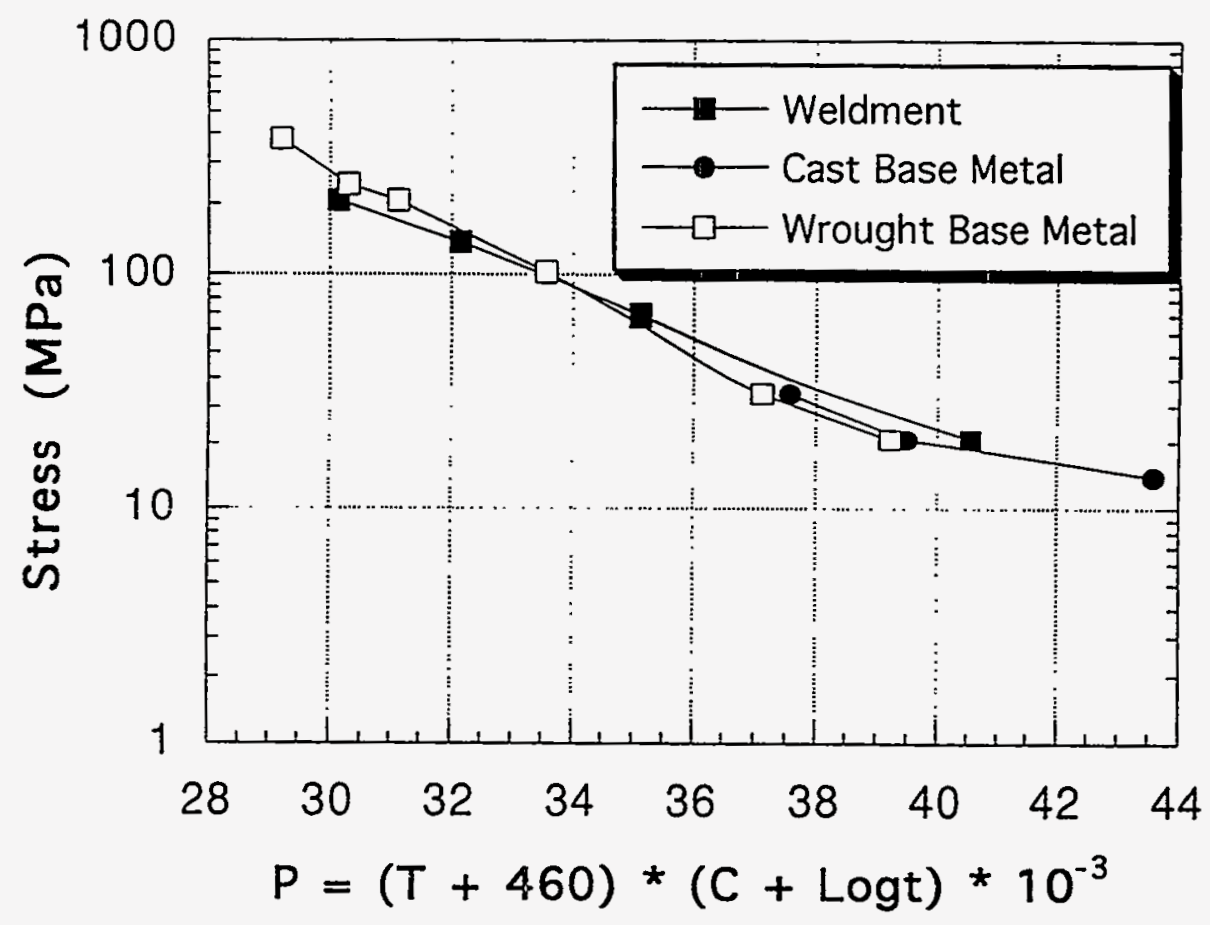

Fig. 9. Comparison of creep-rupture properties of weldment specimens with the as-cast and wrought base-metal specimens.

direction ( $\mathrm{T}-\mathrm{L}$ orientation). The specimens were tested on a 325-J capacity impact tester, and the data are summarized in Table 5. The data, plotted in Fig. 10, were fitted with a hyperbolic tangent function. The lower-shelf energy was fixed at $2 \mathrm{~J}$ and the upper-shelf energy was fixed at the value of the test at $400^{\circ} \mathrm{C}$ for each set of specimens (122 J for the as-welded specimens, $144 \mathrm{~J}$ for the postweld heat-treated specimens).

The results show that the PWHT does improve the toughness of the material. The ductile-to-brittle transition temperature, defined at an energy level midway between the upper- and lower-shelf energy levels, decreases from $245^{\circ} \mathrm{C}$ for the as-welded material to $200^{\circ} \mathrm{C}$ for the material that was given the PWHT, a $45^{\circ} \mathrm{C}$ improvement. The transition temperature is still quite high however. The upper-shelf energy also improves with heat treatment, increasing from 122 to $144 \mathrm{~J}$. The specimens tested at $400^{\circ} \mathrm{C}$ showed completely ductile fracture, and they provide a good estimate of the upper-shelf energy, although only one specimen was tested for each material at high enough temperatures to give fully ductile fracture. 
Table 5. Charpy-impact energy data on weldment specimens from 12 -mm (0.5-in.) -thick plate of FAPY alloy

\begin{tabular}{|c|c|c|c|c|}
\hline \multirow{3}{*}{$\begin{array}{c}\text { Test } \\
\text { temperature } \\
\left({ }^{\circ} \mathrm{C}\right)\end{array}$} & \multicolumn{4}{|c|}{ Charpy-impact energy } \\
\hline & \multicolumn{2}{|c|}{ As welded } & \multicolumn{2}{|c|}{ Postweld heat treated $^{a}$} \\
\hline & $\mathrm{J}$ & $\mathrm{ft} / \mathrm{lb}$ & $\mathrm{J}$ & $\mathrm{ft} / \mathrm{lb}$ \\
\hline $\begin{array}{r}25 \\
100 \\
150 \\
175 \\
200 \\
250 \\
300 \\
400\end{array}$ & $\begin{array}{c}2 \\
5.4 \\
9.5 \\
-- \\
20.3 \\
71.2 \\
100.3 \\
122.0\end{array}$ & $\begin{array}{c}1.5 \\
4.0 \\
7.0 \\
-- \\
15.0 \\
52.5 \\
74.0 \\
90.0\end{array}$ & $\begin{array}{r}2.6 \\
5.3 \\
9.2 \\
20.3 \\
72.5 \\
126.1 \\
143.7\end{array}$ & $\begin{array}{r}1.9 \\
3.9 \\
6.8 \\
15.0 \\
53.5 \\
-- \\
93.0 \\
106.0\end{array}$ \\
\hline
\end{tabular}

apostweld heat treatment at $750^{\circ} \mathrm{C}$ for $1 \mathrm{~h}$.

ORNL-DWG 95-5981

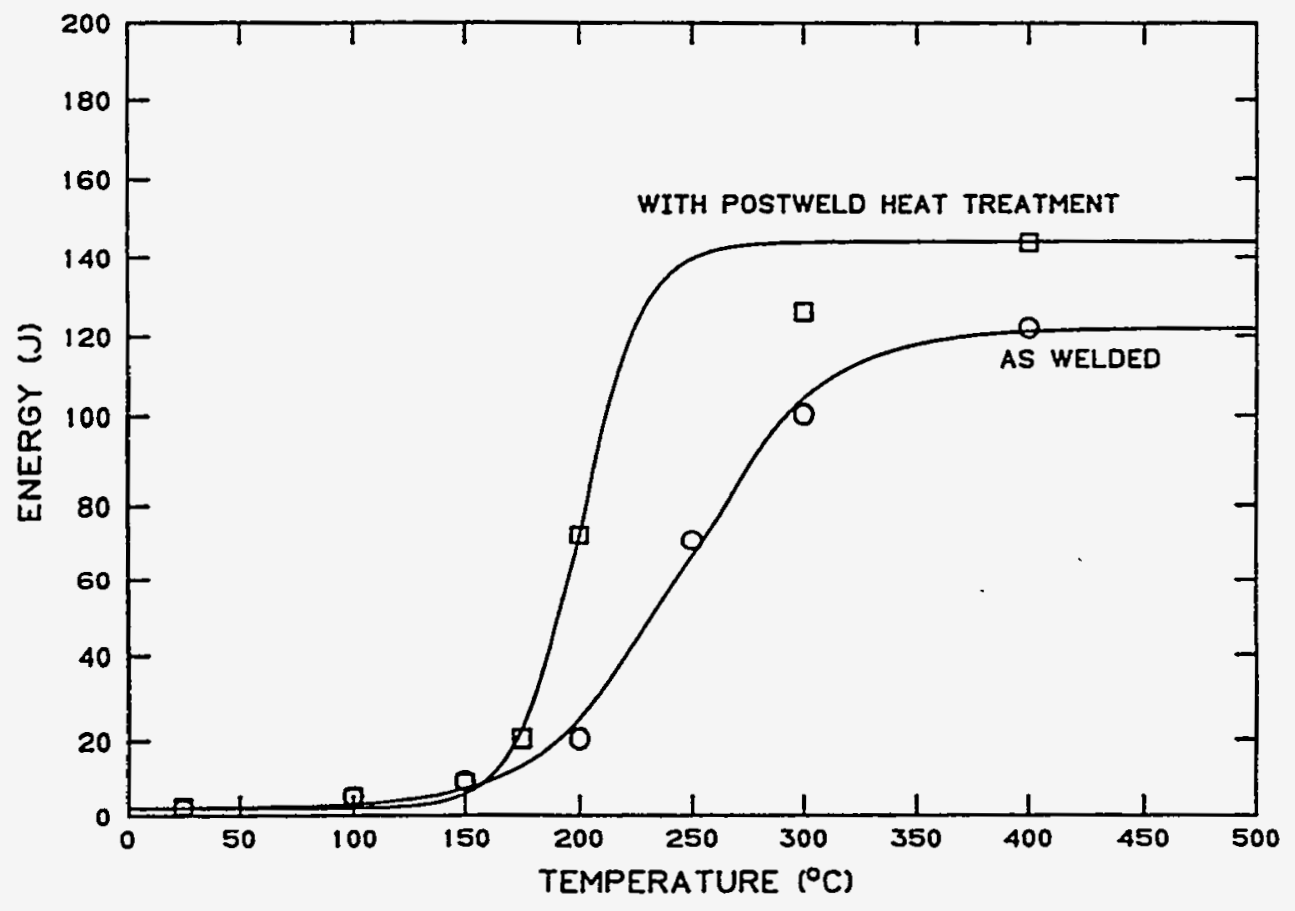

Fig. 10. Plot of Charpy-impact energy of weldment specimens from 12-mm (0.5-in.) -thick cast plate of FAPY alloy. Postweld heat treatment was carried out at $750^{\circ} \mathrm{C}$ for $1 \mathrm{~h}$. 
The Charpy-impact energy data for the weldment specimens are compared with those of the wrought base-metal data in Fig. 11. This figure shows that the transition temperature is approximately $50^{\circ}$ higher for the weldment specimens, and the upper-shelf energy is lower by approximately $100 \mathrm{~J}$. The most likely cause for the higher transition .temperature for the weldment specimens is their much coarser grain size as opposed to the wrought material.

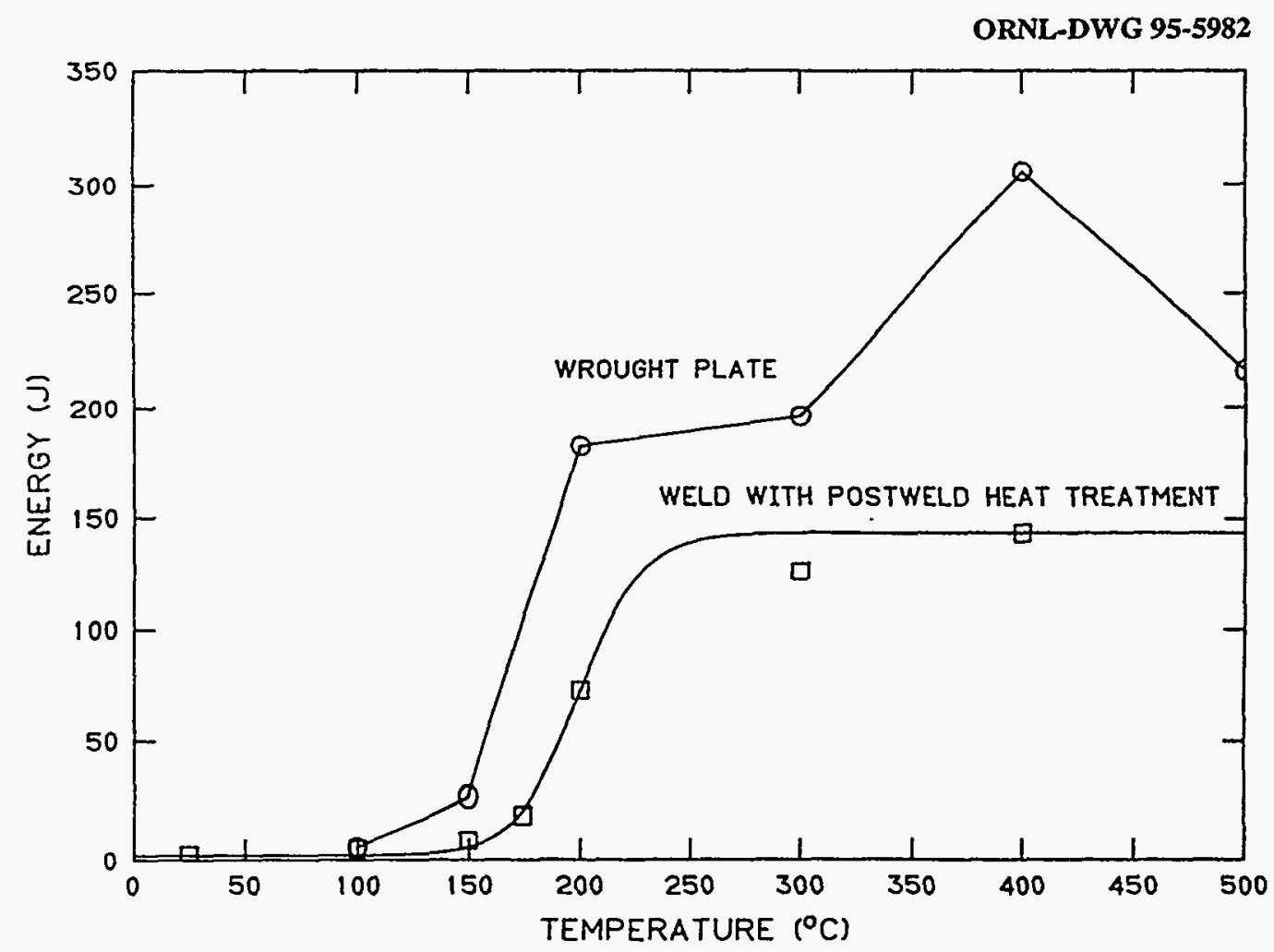

Fig. 11. Comparison of Charpy-impact energy data of weldment specimens with those of base-metal specimens in the wrought condition.

\section{MICROSTRUCTURE AND HARDNESS DATA}

In addition to the macroetched cross sections, photomicrographs of various regions of the weldment were also taken (see Fig. 2). The sets of micrographs for the base metal, heat-affected zone (HAZ), and weld metal for 12-, 25-, and 51-mm (0.5-, 1-, and 2-in.) -thick plates are presented in Figs. 12 through 17. The photomicrographs of the darker banded regions (see Figs. 14 and 15) in the macroetched sections of the 25- and 51-mm (1-and 2-in.) -thick plates showed them to contain equiaxed grain structure. The general 

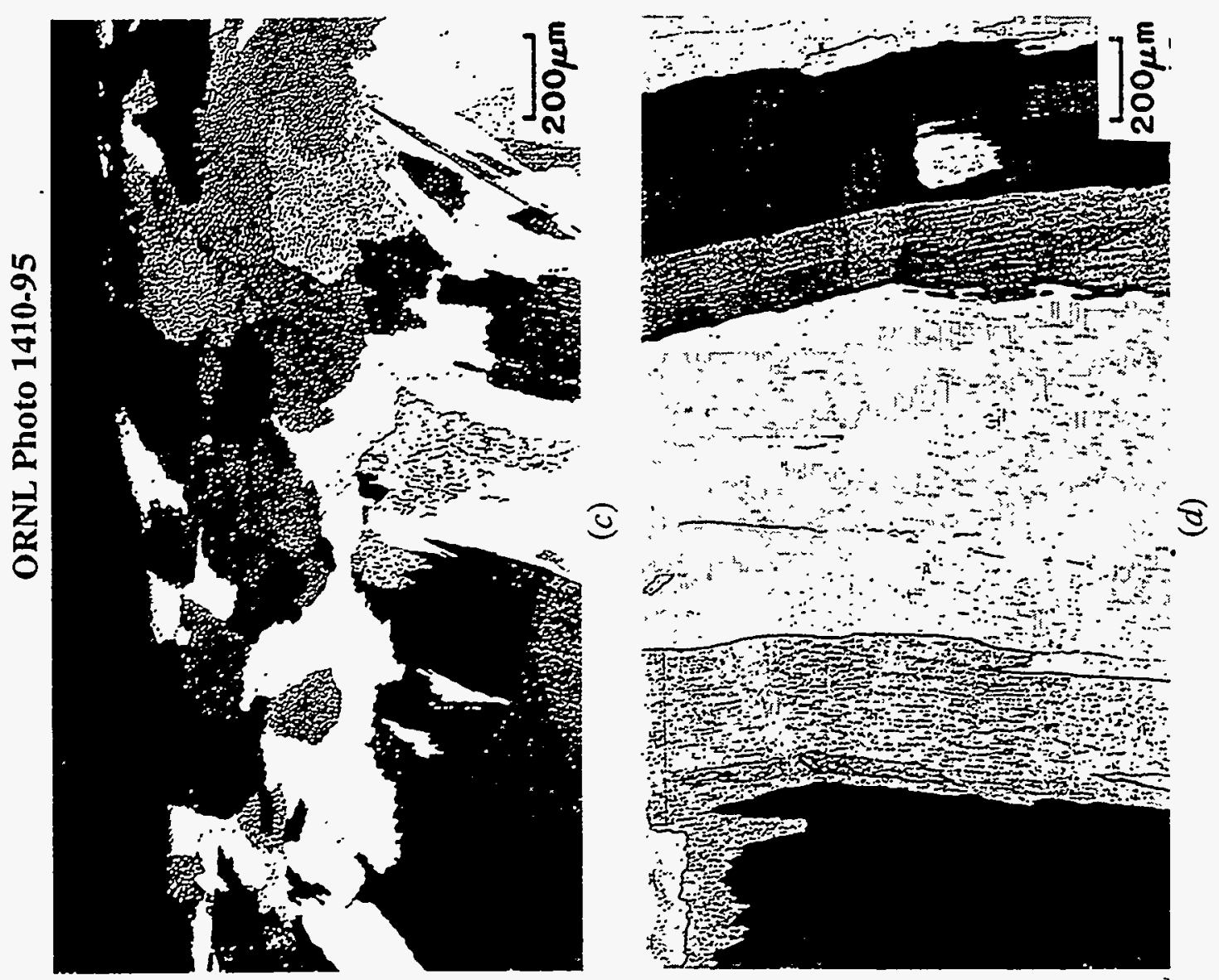

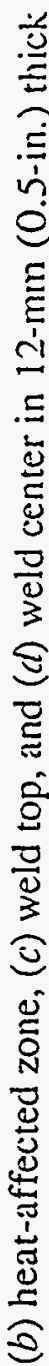

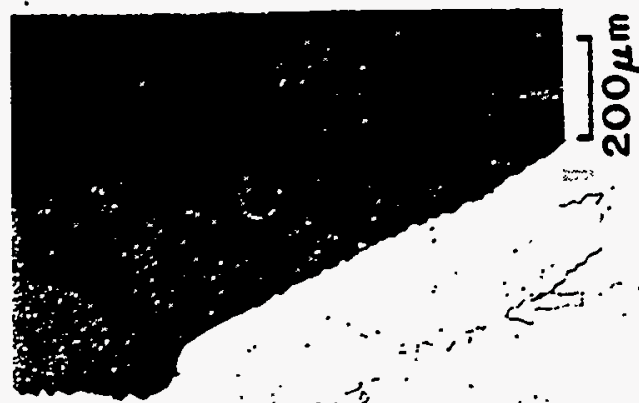

变
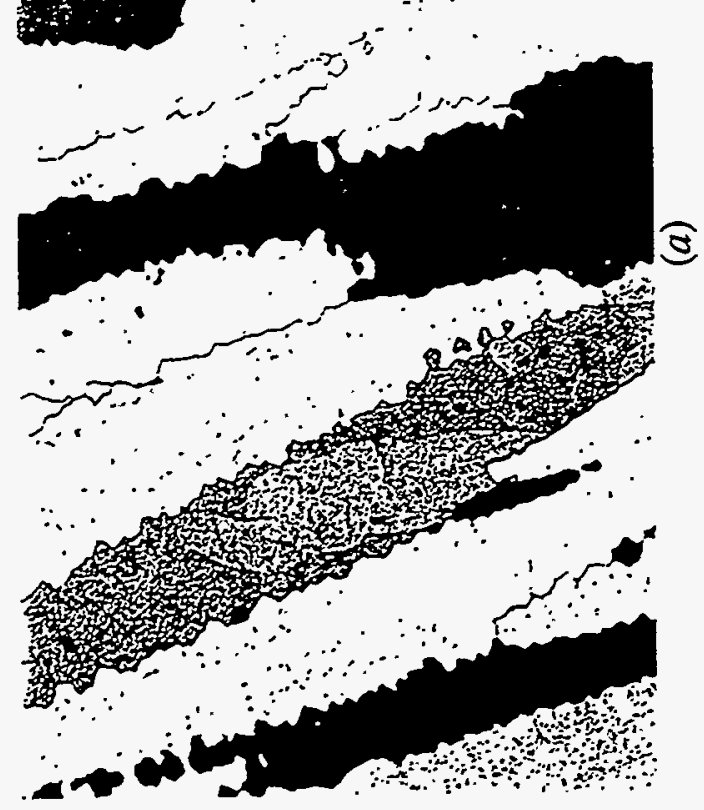

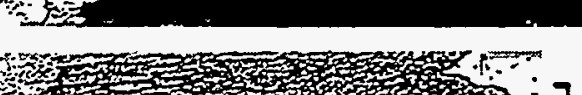

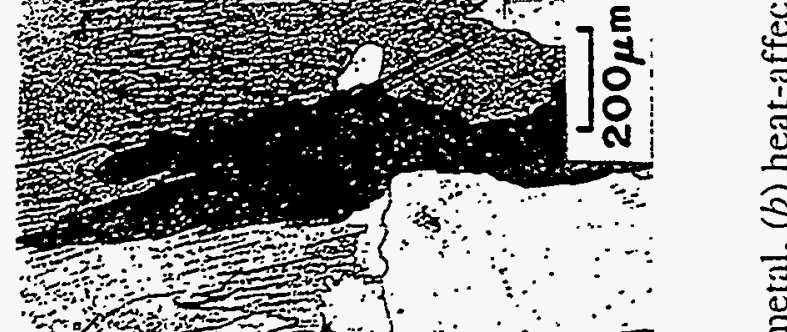

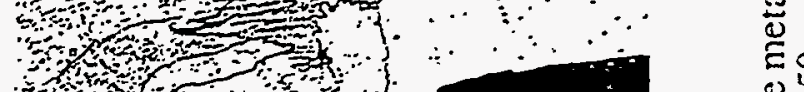
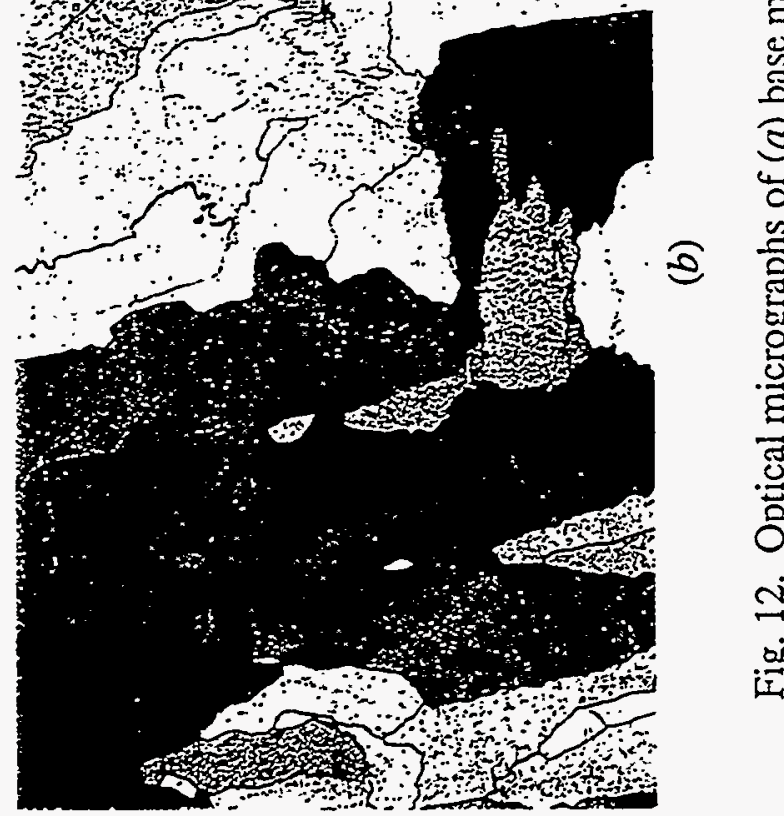

芯.:

ङ을

茨

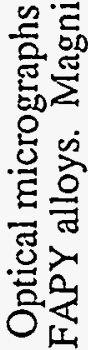

तit

is

玨等

$\frac{\bar{d}}{\frac{0}{1}}$ 

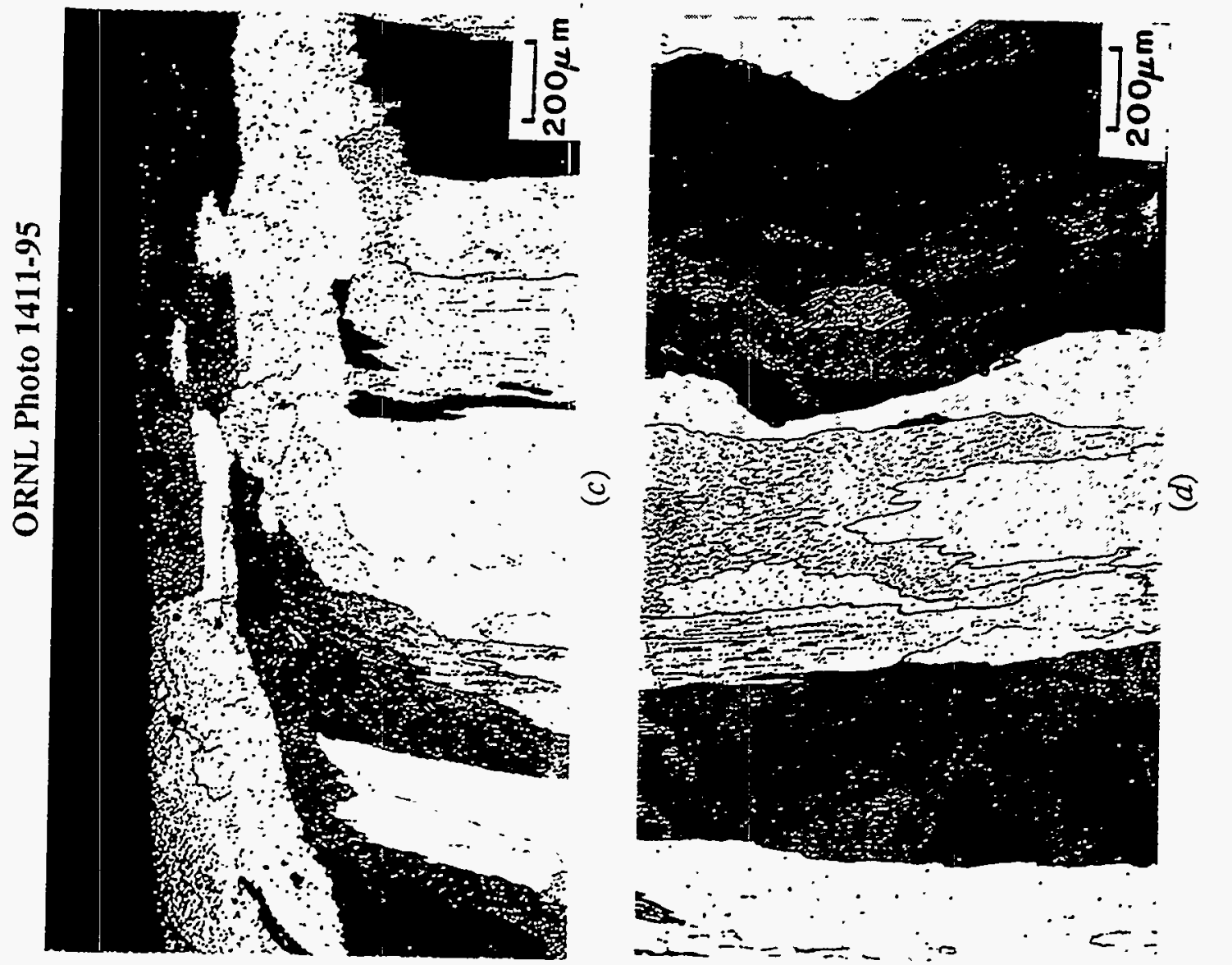

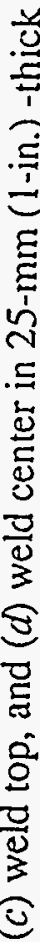
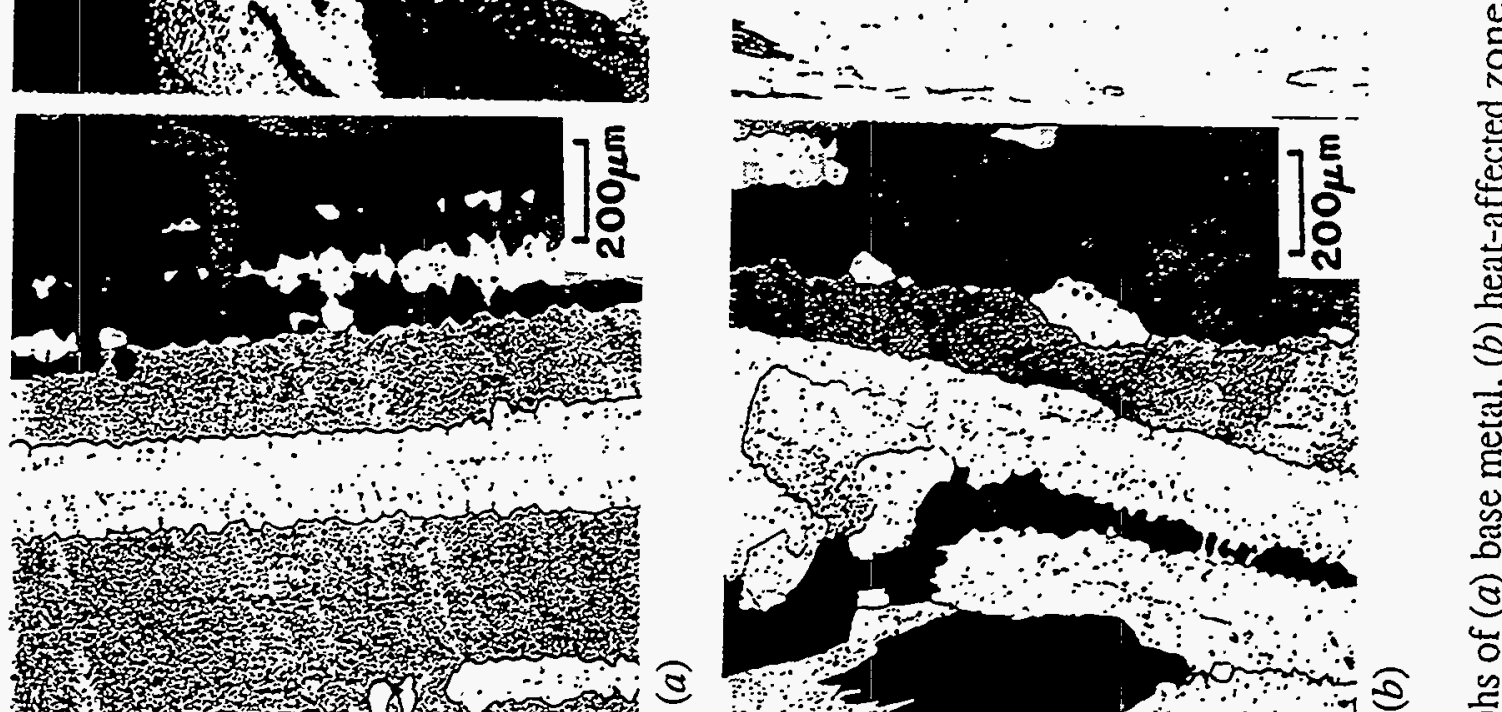

触

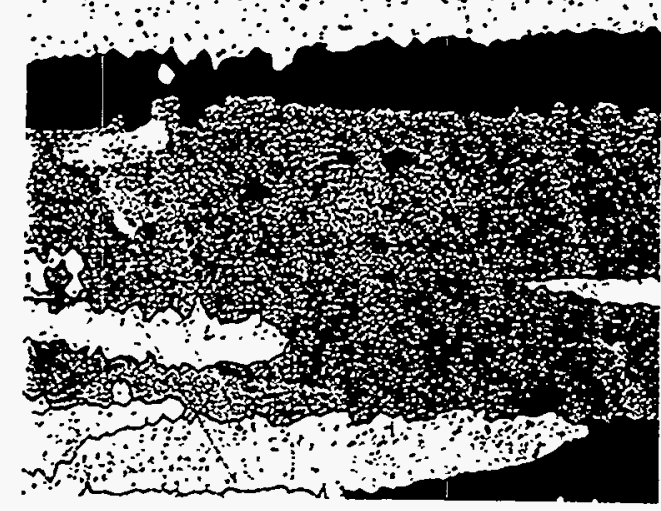

(5)

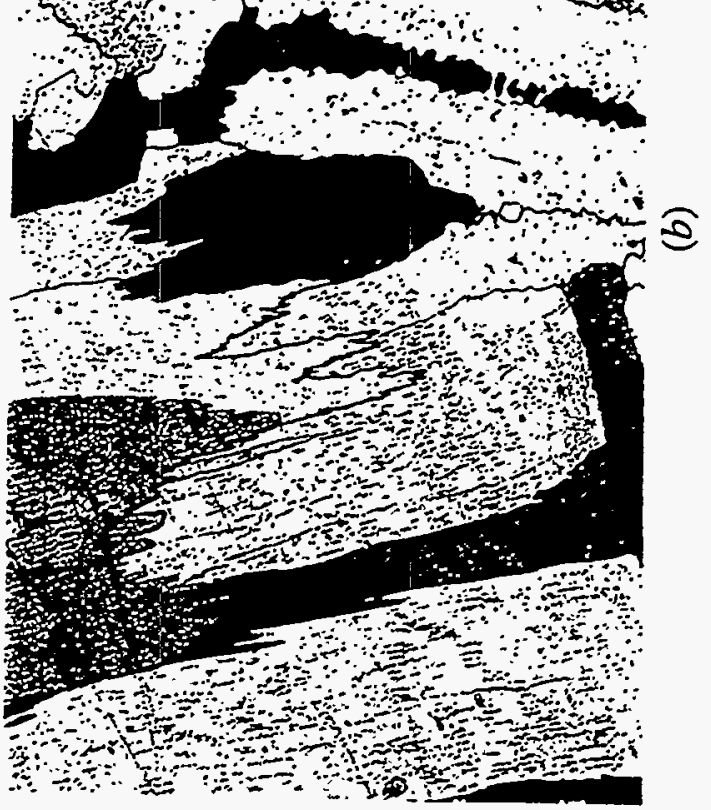




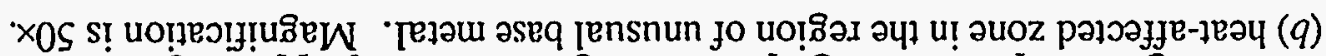

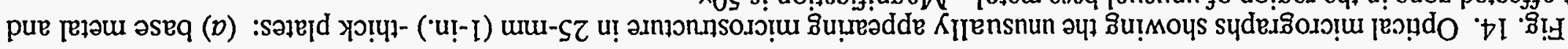

(q)

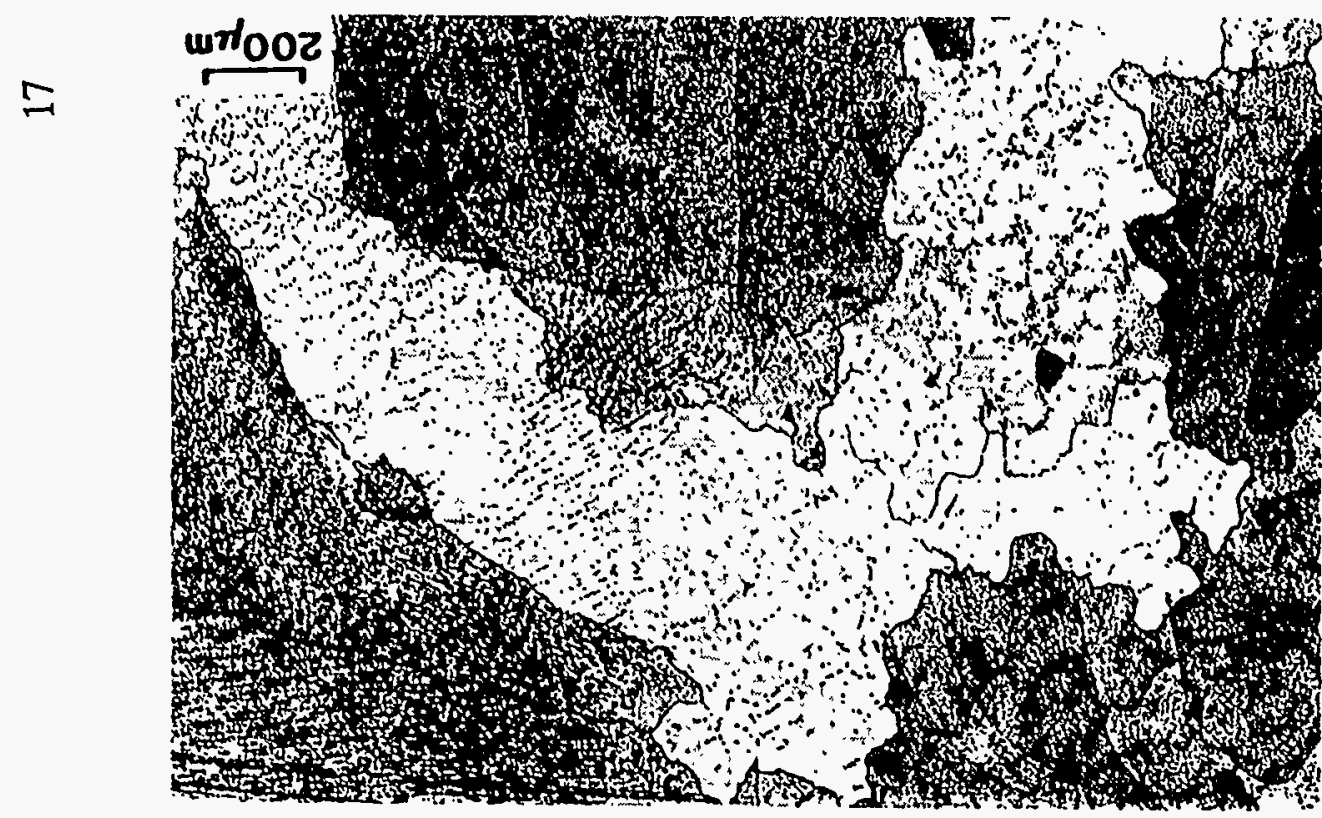

$($ b)

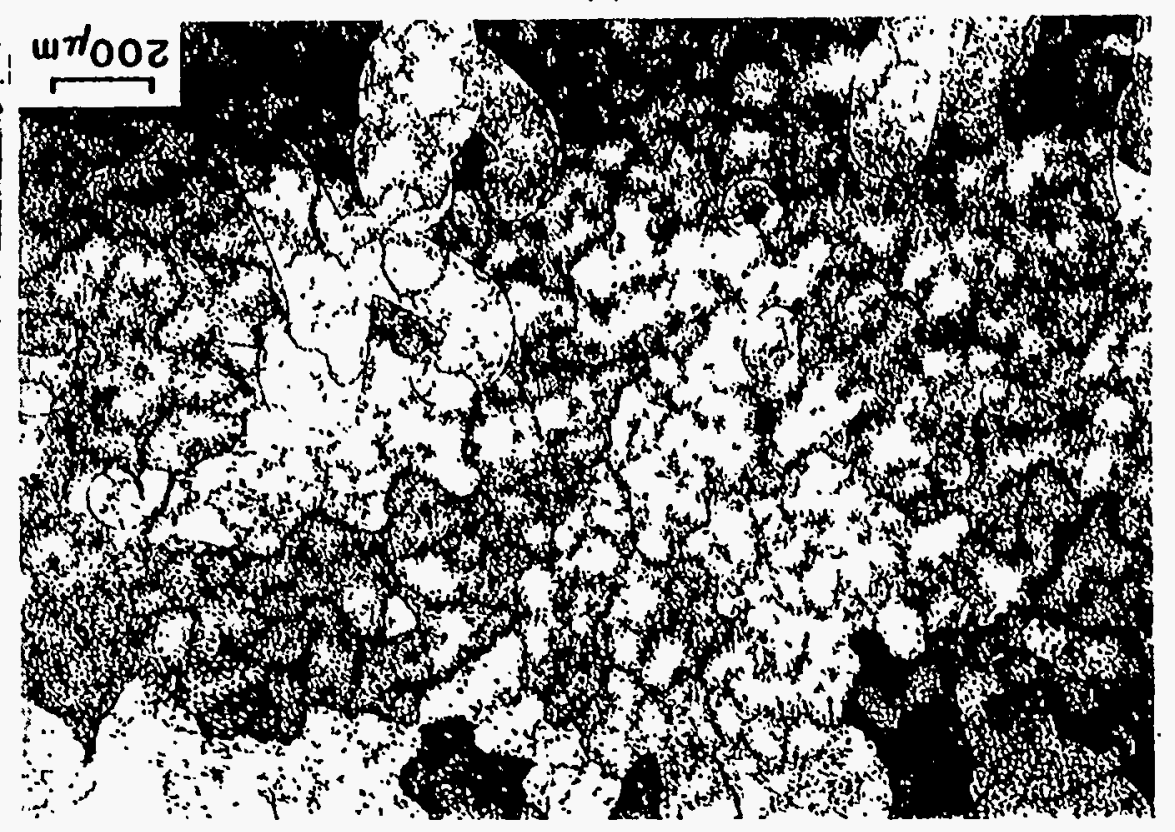




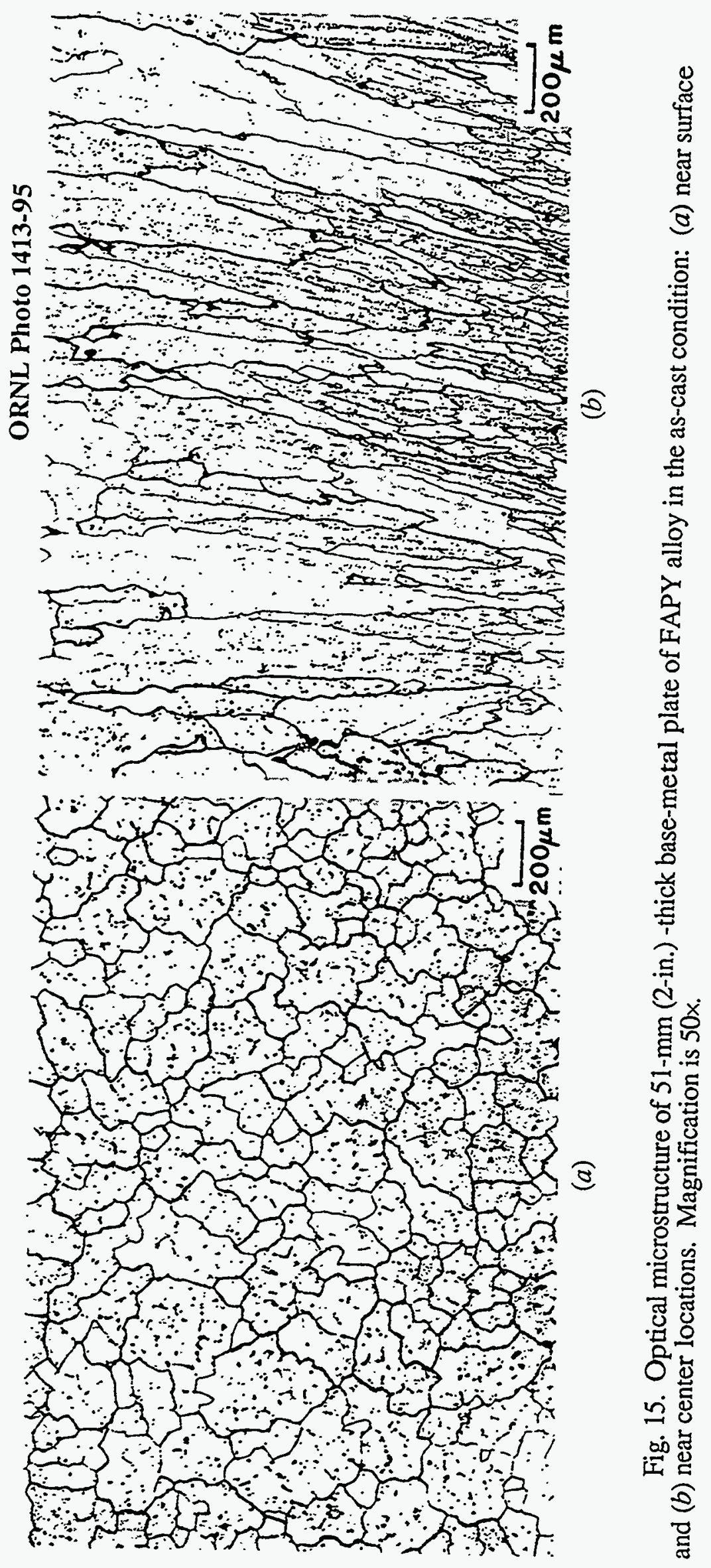




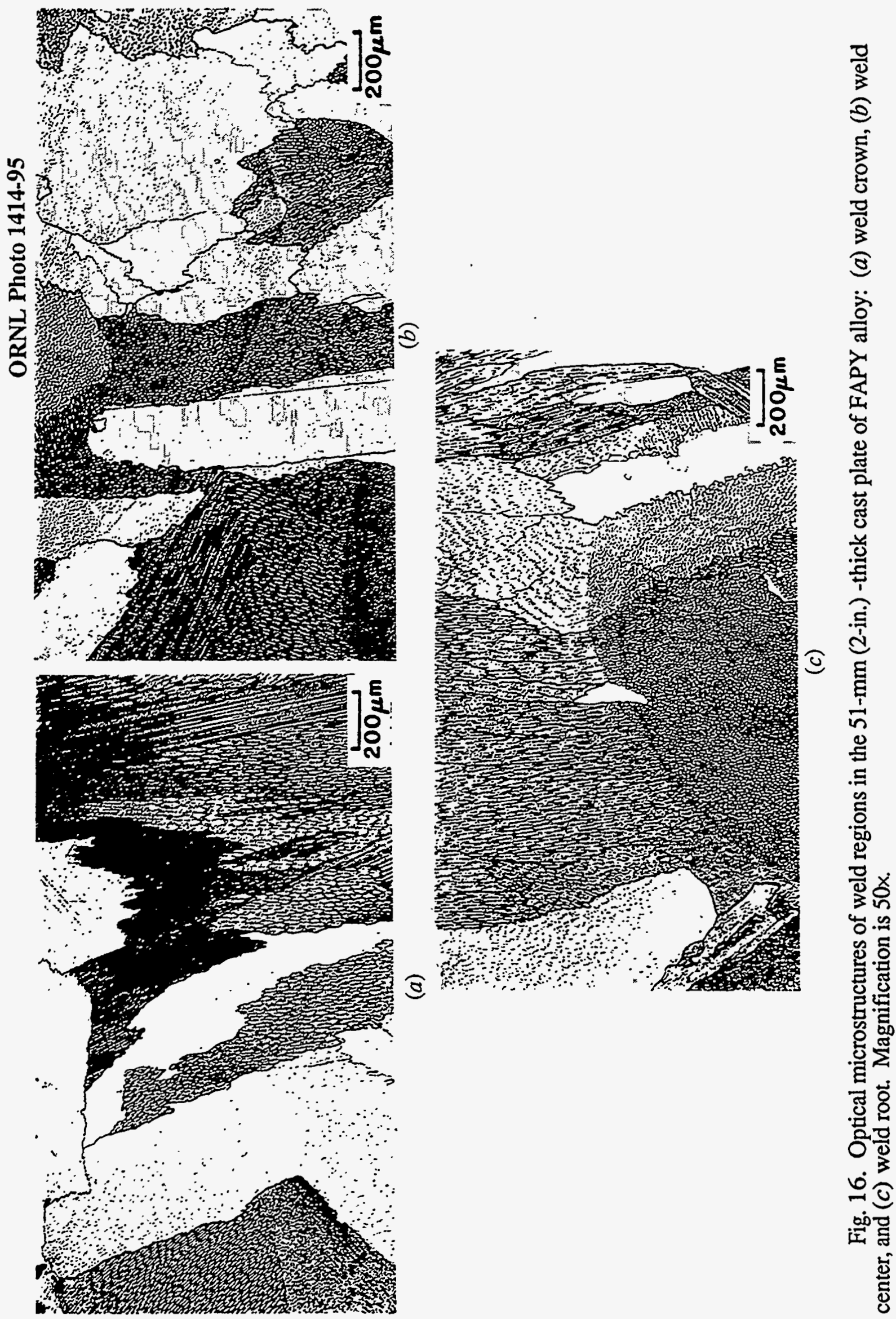




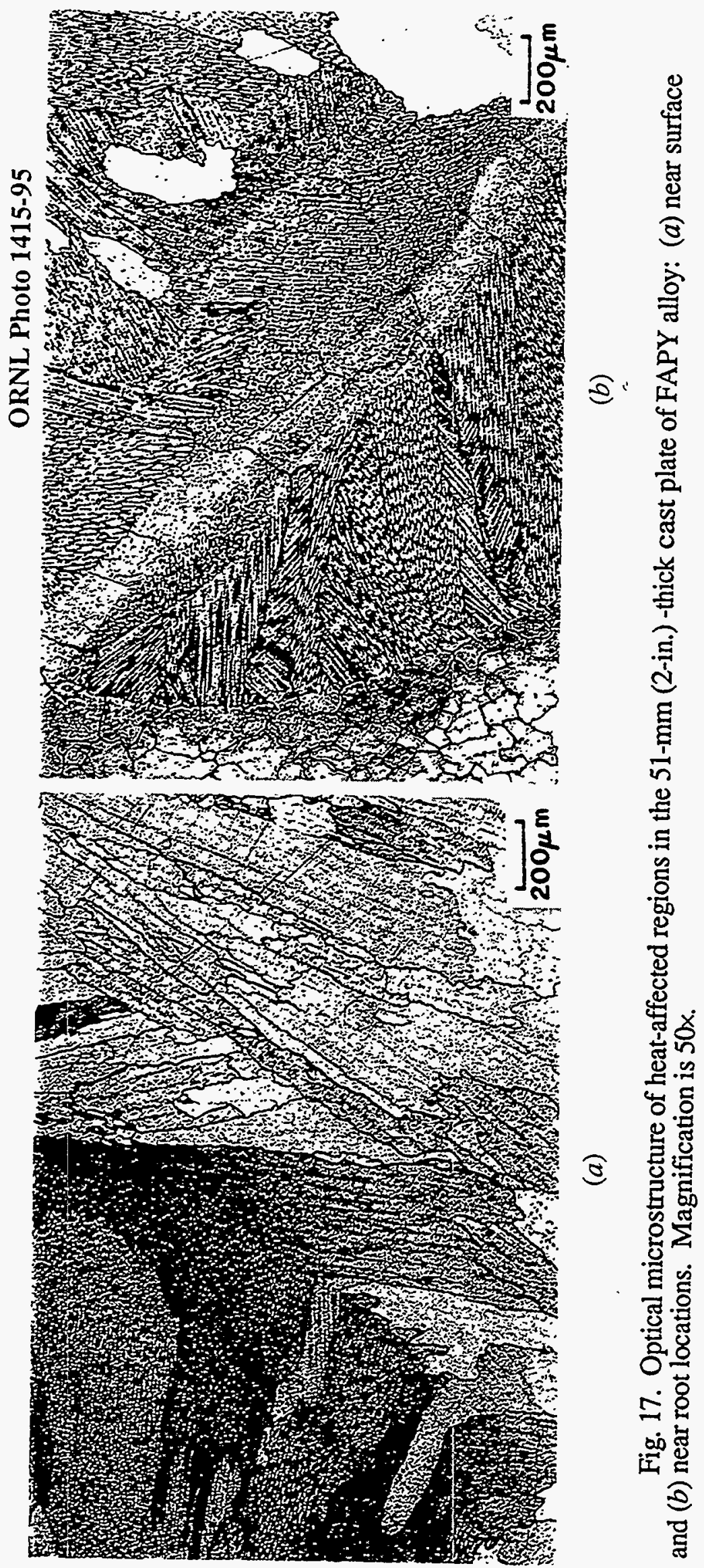


observations from the weldment photomicrographs are: (1) the weld metal has a coarsegrained structure similar to the cast base metal, and (2) the region identified as HAZ shows an epitaxial grain growth of the base-metal grains into the weld metal.

The microhardness data of the base-metal, HAZ, and weld-metal regions show that they are essentially the same for plates of a given thickness (see Table 6). However, there is approximately a 10- to 20-dph point increase in hardness of thicker plates as opposed to a $12-\mathrm{mm}(0.5$-in.) -thick plate. This is probably due to the greater number of passes, thus more thermomechanical cycles, which the thicker plate experiences. Although different in appearance, the banded region of the 25-mm (1-in.) -thick plate has hardness very similar to the base- and weld-metal regions.

Table 6. Microhardness of base, weld, and heat-affected zone of welds in 12-, 25-, and $51-\mathrm{mm}(0.5-, 1-$, and 2 -in.) -thick welded plates in the as-cast condition

\begin{tabular}{ccccc}
\hline \multirow{2}{*}{$\begin{array}{c}\text { Plate } \\
\text { thickness } \\
(\mathrm{mm})\end{array}$} & $\begin{array}{c}\text { Base } \\
\text { metal }\end{array}$ & $\begin{array}{c}\text { Weld } \\
\text { metal }\end{array}$ & $\begin{array}{c}\text { Heat-affected } \\
\text { zone }\end{array}$ & $\begin{array}{c}\text { Base metal and heat-affected } \\
\text { zone in unusual area }\end{array}$ \\
\cline { 2 - 5 } & $223 \pm 4$ & $227 \pm 5$ & $223 \pm 7$ & - \\
12 & $238 \pm 4$ & $237 \pm 6$ & $243 \pm 3$ & $246 \pm 6$ \\
25 & $233 \pm 10$ & $252 \pm 7$ & $238 \pm 4$ & $240 \pm 11$ \\
51 & & &
\end{tabular}

\section{DISCUSSION}

The vacuum-induction-melted and as-cast plates of 12,25 , and $51 \mathrm{~mm}(0.5,1,2 \mathrm{in}$.) thicknesses were successfully welded using the GTA process. All of the welds used a filler wire of base-metal composition. The 12 -mm ( 0.5 -in.) -thick plate could be welded without preheat. However, $25 \mathrm{~mm}(1 \mathrm{in}$.) and thicker sections require preheat to make crack-free welds. The preheat temperature for the FAPY alloy can be as low as $200^{\circ} \mathrm{C}$, which is no different than that required for many ferritic steels. In addition to preheat, a PWHT of $750^{\circ} \mathrm{C}$ is highly desirable for lowering the transition temperature and increasing the uppershelf energy during Charpy-impact testing. 
The microstructure of the starting plates was coarse due to being in the as-cast condition. For the thinner plate of $12 \mathrm{~mm}(0.5 \mathrm{in}$.) thickness, the grain structure was primarily columnar. However, for the plates of 25 and $51 \mathrm{~mm}$ ( 1 and 2 in.) thicknesses, some equiaxed structure was also present in addition to the columnar structure. The weld region also showed a coarse-grained microstructure similar to the cast structure of the base metal. Epitaxial growth of base-metal grains into the weld region was observed. No distinct transition in microstructure was observed from the base- to the weld-metal regions. This observation was confirmed by noting essentially the same microhardness values for base-metal, HAZ, and the weld-metal region. The uniformity in microstructure and microhardness was also confirmed by the failure of the tensile specimens in the middle of the gage section, which normally happens for a material of uniform properties.

The similarity in microstructure and microhardness of the base and weld metals yielded tensile properties of the weldment specimens to match the base-metal properties. A similar match was also observed for the creep-rupture properties. It is important to note that although the properties of the weldment specimens matched the base-metal properties in the as-cast condition, the ductility values for FAPY alloy are low at temperatures $\leq 100^{\circ} \mathrm{C}$.

An unusual event of cracking was observed in this weldment section of the 51-mm (2-in.) -thick plate during the etching process to reveal its macrostructure. The acid-etching process is known to produce hydrogen, and it is this hydrogen that is believed to have caused the cracking. This cracking was observed only in the 51-mm (2-in.) -thick plate and not in the plates of 12 and $25 \mathrm{~mm}(0.5$ and $1 \mathrm{in}$.) thicknesses. Since the hydrogen-related cracking typically requires the combination of stress and the presence of hydrogen, it is believed that a PWHT of $750^{\circ} \mathrm{C}$ was not adequate to relieve the welding stresses for the 51-mm (2-in.) -thick plate. However, the same PWHT must have been adequate for the thinner sections, which had lower welding stresses to start with because of their thinner sections. Thus, it is believed that a higher preheat or PWHT temperature than $750^{\circ} \mathrm{C}$ may be required for section sizes of $\geq 51 \mathrm{~mm}$ ( $2 \mathrm{in}$.). Additional work is required to establish the preheat and/or PWHT requirements as a function of section thickness for the FAPY alloy. 


\section{SUMMARY AND CONCLUSIONS}

The as-cast plates of 12-, 25-, and 51-mm (0.5-, 1-, and 3.2-in.) thicknesses of FAPY alloy were welded using the GTA process and a 3.2-mm (0.125-in.) -diam filler wire of matching composition. Welds were made without any preheat and with preheats of 200 and $350^{\circ} \mathrm{C}$. Crack-free welds could be prepared in 12-mm (0.5-in.) -thick plates without preheat. However, the thicker plates required a preheat for crack-free welds, and a temperature of $200^{\circ} \mathrm{C}$ was acceptable up to plate thickness of $51 \mathrm{~mm}$ ( 2 in.). The preheat temperature for thicker sections may be higher and needs to be determined. The PWHT at $750^{\circ} \mathrm{C}$ for $1 \mathrm{~h}$ was found to lower the transition temperature and increase the upper-shelf energy during Charpy-impact testing of the 12 -mm (0.5-in.) -thick welded plate. Thus, all the other weldment properties were determined in the postweld heat-treated condition. Tensile and creep properties of the weldment specimens matched the properties of the base metal. These results were explained on the basis that the microstructure and microhardness of the weld region were similar to the base metal.

Major conclusions from this study include:

1. The cast plates of the FAPY alloy can be welded by a commonly used GTA process. A filler wire of composition matching the base metal is acceptable. No preheat is required for plates of $12 \mathrm{~mm}(0.5 \mathrm{in}$.) thickness. Plates of $\geq 25 \mathrm{~mm}$ ( 1 in.) thickness require a preheat of at least $200^{\circ} \mathrm{C}$. A PWHT at $750^{\circ} \mathrm{C}$ for $1 \mathrm{~h}$ is desirable to improve the Charpy-impact properties and to reduce the suceptibility of the weld to hydrogenrelated cracking. A PWHT temperature of higher than $750^{\circ} \mathrm{C}$ is probably required to eliminate the hydrogen-related cracking in the 51-mm (2-in.) -thick welds. However, a correlation of PWHT as a function of section thickness needs to be developed.

2. Tensile and creep properties of the weldment specimens matched that of the base metal. These results are explained on the basis that the microhardness and microstructure of the welds are very similar to the base metal. 


\section{FUTURE WORK}

Additional work is required on welding of thicker sections of the FAPY alloy:

1. Prepare welds in a section thickness greater than $51 \mathrm{~mm}$ ( $2 \mathrm{in}$.), and determine the PWHT temperatures to eliminate hydrogen-related cracking. Macroetching solution can be used to determine the presence of hydrogen-related cracking.

2. Determine the effect of PWHT temperature on Charpy-impact properties. Use these data to select the optimum temperature for the best combination of transition temperature and upper-shelf energy.

3. Determine additional weldment creep tests to obtain data for rupture times exceeding $1000 \mathrm{~h}$.

\section{ACKNOWLEDGMENTS}

The authors thank J. D. Vought for melting the alloys, D. W. Swaney and J. D. McNabb for welding the alloys, L. K. Egner for tensile and creep testing, E. T. Manneschmidt for Charpy-impact testing, H. F. Longmire for metallography, M. L. Santella and C. G. McKamey for reviewing the report, K. Spence for editing, M. L. Atchley for preparation of the report, M. R. Upton for final makeup and composition, and G. R. Carter for quality assurance review.

\section{REFERENCES}

1. S. Vyas, S. Viswanathan, and V. K. Sikka, "Effect of Aluminum Content on Environmental Embrittlement in Binary Iron-Aluminum Alloys," Scr. Metall.Mater. 27, $185-90(1992)$. 
ORNL/TM-12944

\section{INTERNAL DISTRIBUTION}

1-2. Central Research Library

3. Document Reference Section

4-5. Laboratory Reference Section

6. Laboratory Records, ORNL RC

7. ORNL Patent Section

8-10. M\&C Records Office

11-15. D. J. Alexander

16. N. C. Cole

17-21. G. M. Goodwin

22. G. W. Griest

23. H. W. Hayden, Jr.

24-28. C. R. Howell

29. R. R. Judkins
30. J. F. King

31. C. G. McKamey

32. R. K. Nanstad

33. S. J. Pawel

34-39. V. K. Sikka

40. R. W. Swindeman

41. S. Viswanathan

42. $X$. Wang

43. H. W. Foglesong (Consultant)

44. E. L. Menger (Consultant)

45. J. G. Simon (Consultant)

46. K. E. Spear (Consultant)

\section{EXTERNAL DISTRIBUTION}

47. ABB COMBUSTION ENGINEERING SYSTEMS, 1119 Riverfront Parkway, Chattanooga, TN 37402
D. A. Canonico

48. AIR FORCE WRIGHT AERONAUTTCAL LABORATORIES, Metals and Ceramics Division, Wright-Patterson Air Force Base, OH 45433

D. M. Dimiduk

49-50. AIR PRODUCTS AND CHEMICALS, P.O. Box 538, Allentown, PA 18105

S. W. Dean

S. C. Weiner

51. ALBERTA RESEARCH COUNCL, Oil Sands Research Department, P.O. Box 8330, Postal Station F, Edmonton, Alberta, Canada T6H5X2

L. G. S. Gray

52-53. ALLISON GAS TURBINE DIVISION, P.O. Box 420, Indianapolis, IN 46206-0420

P. Khandelwai (Speed Code W-5)

R. A. Wenglarz (Speed Code W-16) 
54. ALUMINUM COMPANY OF AMERICA LABORATORIES, Alcoa Technical Center, Route 780, Seventh Street Road, Alcoa Center, PA 15269

G. MacZura

55. AMERICAN WELDING SOCIETY, 550 LeJeune Road, Miami, FL 33126

H. G. Ziegenfuss

56. AMETEK SPECIALTY METAL PRODUCTS DIVISION, Route 519,

P.O. Box 427, Eighty Four, PA 15330

J. H. Reinshagen

57. ARGONNEL NATIONAL LABORATORY, Materials Science and Technology Division, 9700 S. Cass Ave., Argonne, $\mathbb{L} 60439$

K. Natesan

58-59. BABCOCK \& WILCOX COMPANY, 20 S. Van Buren Avenue, Barberton, $\mathrm{OH} 44203$

M. Gold

J. E. Mack

60. BATTELLE-COLUMBUS LABORATORIES, 505 King Avenue, Columbus, $\mathrm{OH} 43201$

I. G. Wright

61-62. BETHLEHEM STEEL CORPORATION, Homer Research Laboratory, Bethlehem, PA 18016

B. L. Bramfitt

J. M. Chilton

63-65. BRITISH COAL CORPORATION, Coal Research Establishment,

Stoke orchard, Cheltenham, Gloucester, England GL524RZ
M. Arnold
C. Bower
A. Twigg

66. BRITISH GAS CORPORATION, Westfield Development Centre, Cardenden, Fife, Scotland KY5OHP

J. E. Scott

67. BROOKHAVEN NATIONAL LABORATORY, Department of Applied Science, Upton, Long Island, NY 11973

T. E. O'Hare 
68-69. CANADA CENTER FOR MINERAL \& ENERGY TECHNOLOGY, 568 Booth Street, Ottawa, Ontario, Canada K1A OG1

R. Winston Revie

M. Sahoo

70. CARNEGIE-MELLON UNIVERSITY, Department of Metallurgical Engineering and Materials Science, Pittsburgh, PA 15213

T. B. Massalski

71. COLORADO SCHOOL OF MINES, Department of Metallurgical Engineering, Golden, CO 80401

G. R. Edwards

72-73. CORNELL UNIVERSITY, Ithaca, NY 14850

Che-Yu Li

S. L. Sass

74. DYNAMET, INC., 195 Museum Road, Washington, PA 15301

L. W. Lherbier

75. EC TECHNOLOGIES, INC., 3614 Highpoint Drive, San Antonio, TX 78217

D. J. Kenton

76-77. EG\&G IDAHO, INC., Idaho National Engineering Laboratory, P.O. Box 1625, Idaho Falls, ID 83415

J. E. Flinn

R. N. Wright

78-80. ELECTRIC POWER RESEARCH INSTTTUTE, 3412 Hillview Avenue,

P.O. Box 10412, Palo Alto, CA 94303

W. T. Bakker

D. J. Frey

J. Stringer

81. EXXON RESEARCH AND ENGINEERING COMPANY, Clinton Township, Route 2, East, Annadale, NJ 08801

M. L. Gorbaty

82. FOSTER WHEELER DEVELOPMENT CORPORATION, 12 Peach Tree Hill Road, Livingston, NJ 07939

J.L. Bough 
83-84. GARRETT TURBINE ENGINE COMPANY, Advanced Materials, Materials Engineering, 111 South 34 Street, P.O. Box 5217, Phoenix, AZ 85010

G. S. Hoppin

B. Keiser

85. GENERAL ATOMICS, P.O. Box 81608, San Diego, CA 92318

D. I. Roberts

86-88. GENERAL ELECTRIC COMPANY, Schenectady, NY 12345

K. M. Chang (Bldg. 81, Room E102)

R. W. Haskell (Bldg. 55, Room 115)

S. C. Huang (Bldg 81, Room E102)

89. GENERAL ELECTRIC COMPANY, Corporate Research and Development, P.O. Box 8, Schenectady, NY 12301

R. L. Fleischer

90. GENERAL ELECTRIC COMPANY, Quartz and Chemicals Department, 24400 Highland Road, Richmond Heights, OH 44413

G. W. Weber

91. HAYNES INTERNATIONL, Technology Dept., 1020 W. Park Avenue, Kokomo, IN 46901
A. Asphahani

92. INSTITUTE OF DEFENSE ANALYSES, 1801 Beauregard Street, Alexandria, VA 22311

T. F. Kearns

93. LAWRENCE LIVERMORE LABORATORY, P.O. Box 808, L-325, Livermore, CA 94550

W. A. Steele

94. LEHIGH UNIVERSITY, Materials Research Center, Bethlehem, PA 18015

Y. T. Chou

95. LOCKHEED CORPORATION, Palo Alto Laboratories, 3251 Hanover Street, Palo Alto, CA 94303

E. C. Burke 
96-98. LOS ALAMOS NATIONAL LABORATORY, Los Alamos, NM 87545
S. P. Chen
P. J. Hay
R. S. Skaggs

99. THE MATERIALS PROPERTIES COUNCIL, INC., 345 E. Forty-Seventh Street, New York, NY 10017

M. Prager

100-101. MICHIGAN TECHNOLOGICAL UNIVERSITY, Department of Metallurgical Engineering, Houghton, MI 49931

D. Mikkola

C. L. White

102. MONSANTO COMPANY, P.O. Box 1311, Texas City, TX 77550

P. S. Gupton

103. NATIONAL INSTITUTE OF STANDARDS AND TECHNOLOGY, Materials Building, Gaithersburg, MD 20899

L. K. Ives

104. NAVAL SURFACE WEAPONS CENTER, Code R32, White Oak, Silver Spring, MD 20910

H. M. DeJarnette

105. NAVAL SURFACE WEAPONS CENTER, Surface Weapons Materials Technology Program, Dahlgren, VA 22448

W. T. Messick

106. NORTH CAROLINA STATE UNIVERSITY, Materials Engineering Dept., Raleigh, NC 27650

C. C. Koch

107. OAK RIDGE INSTITUTE OF SCIENCE AND EDUCATION LIBRARY, Oak Ridge, TN 37831

MERT Division

108. RENSSELAER POLYTECHNIC INSTITUTE, Materials Engineering Department, Troy, NY 12181

N. S. Stoloff 
109. RESEARCH TRIANGLE INSTITUTE, P.O. Box 12194, Research Triangle Park, NC 27709

T. W. Sigmon

110. SHELL DEVELOPMENT COMPANY, P.O. Box 1380, Houston, TX 77251-1380

L. W. R. Dicks

111. SORELL CONSULTING SERVICES, 49 Brookside Terrace, North Caldwell, NJ 07006

G. Sorell

112. THE JOHN HOPKINS UNIVERSITY, Materials Science and Engineering, Maryland Hall, Baltimore, ND 21218

R. E. Green, Jr.

113. THE TIMKEN COMPANY, 1835 Dueber Avenue, SW, Canton, OH 44706

P. W. Lee

114. THE TORRINGTON COMPANY, Advanced Technology Center, 59 Field Street, Torrington, CT 06790

W. J. Chmura

115. UNION CARIBE CORPORATION, Linde Division, P.O. Box 44, 175 East Park Drive, Towanda, NY 14151-0044

H. Cheung

116. UNITED TECHNOLOGIES, Pratt and Whitney, Engineering Division, North, 400 Main St., East Hartford, CT 06108

D. N. Duhl

117. UNIVERSAL CYCLOPS SPECIALTY STEEL DIVISION, 650 Washington Road, Pittsburgh, PA 15228

H. L. Black

118. UNIVERSAL ENERGY SYSTEMS, INC., 4401 Dayton-Xenia Road, Dayton, OH 45432

M. G. Mendiratta 
119. UNIVERSITY OF CALIFORNIA AT BERKELEY, Department of Materials Science and Mineral Engineering, Berkeley, CA 94720

R. O. Ritchie

120. UNIVERSITY OF MASSACHUSETTS, Department of Polymer Science, Room 701, GRC, Amherst, MA 01003

R. S. Porter

121. UNIVERSITY OF NOTRE DAME, Department of Materials Science and Engineering, P.O. Box E, Notre Dame, IN 46556

T. H. Kosel

122-124. UNIVERSITY OF TENNESSEE AT KNOXVILLE, Materials Science and Engineering, Knoxville, TN 37996

C. R. Brooks

R. A. Buchanan

C. D. Lundin

125. UNIVERSITY OF TENNESSEE SPACE INSTITUTE, Tullahoma, TN 37388

J. W. Muehlhauser

126. UNIVERSITY OF WASHINGTON, Department of Materials Science and Engineering, 101 Wilson, FB-10, Seattle, WA 98195

T. G. Stoebe

127. VANDERBILT UNIVERSITY, Station B, P.O. Box 1621, Nashville, TN 37235

J. J. Wert

128. VIRGINIA POLYTECHNIC INSTITUTE AND STATE UNIVERSITY, Blacksburg, VA 24016

D. A. Farkas

129. WESTERN RESEARCH INSTITUTE, 365 N. 9th Street, P.O. Box 3395, University Station, Laramie, WY 82071

V. K. Sethi

130. WESTINGHOUSE ELECTRIC CORPORATION, Research and Development Center, 1310 Beulah Road, Pittsburgh, PA 15234

S. C. Singhal 
131. WESTINGHOUSE HANFORD COMPANY, P.O. Box 1970, W/A-65, Richland, WA 99352

R. N. Johnson

132-134. DOE, ENERGY SYSTEMS RESEARCH AND DEVELOPMENT, Office of Conservation and Renewable Energy, Forrestal Building, Independence Avenue, Washington, DC 20585

J. J. Brogan

J. J. Eberhardt

S. M. Wolf

135-140. DOE, MORGANTOWN ENERGY TECHNOLOGY CENTER, P.O. Box 880, Morgantown, WV 26505
R. A. Bajura
R. C. Bedick
J. W. Byam, Jr.
R. J. Dellfield
J. M. Hobday
J. S. Wilson

141-144. DOE, PITTSBURGH ENERGY TECHNOLOGY CENTER, P.O. Box 10940, Pittsburgh, PA 10940
A. L. Baldwin
G. V. McGurl
R. Santore
T. M. Torkos

145. DOE, OFFICE OF BASIC ENERGY SCIENCES, Materials Sciences

Division, ER-131 GTN, Washington, DC 20545

J. B. Darby

146. DOE, OFFICE OF FOSSIL ENERGY, Washington, DC 20545

J. P. Carr, FE-14

147. DOE, OFFICE OF VEHICLE AND ENGINE RESEARCH AND DEVELOPMENT, Route Symbol CE-131, Forrestal Building, Washington, DC 20585

R. B. Schulz 
148-149. DOE, OAK RIDGE OPERATIONS OFFICE, P.O. Box 2001, Oak Ridge, TN $37831-8600$

Assistant Manager for Energy Research and Development E. E. Hoffman

150-151. DOE, OFFICE OF SCIENTIFIC AND TECHNICAL INFORMATION, Office of Information Services, P.O. Box 62, Oak Ridge, TN 37831

For distribution by microfiche as shown in DOE/OSTI-4500, Distribution Categories UC-103 (Fluidized Bed Combusion), UC-109 [Coal Gasification (Surface and Underground), and UC-114 (Coal-Based Materials and Components) 